\title{
(Niet) schudden voor gebruik : pleidooi voor een schok-therapie in West-Europa en een geleidelijke overgang in Oost-Europa
}

Citation for published version (APA):

de Neubourg, C. R. J. (1994). (Niet) schudden voor gebruik : pleidooi voor een schok-therapie in WestEuropa en een geleidelijke overgang in Oost-Europa. Datawyse / Universitaire Pers Maastricht. https://doi.org/10.26481/spe.19940331cn

Document status and date:

Published: 31/03/1994

DOI:

10.26481/spe.19940331cn

Document Version:

Publisher's PDF, also known as Version of record

Please check the document version of this publication:

- A submitted manuscript is the version of the article upon submission and before peer-review. There can be important differences between the submitted version and the official published version of record.

People interested in the research are advised to contact the author for the final version of the publication, or visit the DOI to the publisher's website.

- The final author version and the galley proof are versions of the publication after peer review.

- The final published version features the final layout of the paper including the volume, issue and page numbers.

Link to publication

\footnotetext{
General rights rights.

- You may freely distribute the URL identifying the publication in the public portal. please follow below link for the End User Agreement:

www.umlib.nl/taverne-license

Take down policy

If you believe that this document breaches copyright please contact us at:

repository@maastrichtuniversity.nl

providing details and we will investigate your claim.
}

Copyright and moral rights for the publications made accessible in the public portal are retained by the authors and/or other copyright owners and it is a condition of accessing publications that users recognise and abide by the legal requirements associated with these

- Users may download and print one copy of any publication from the public portal for the purpose of private study or research.

- You may not further distribute the material or use it for any profit-making activity or commercial gain

If the publication is distributed under the terms of Article $25 \mathrm{fa}$ of the Dutch Copyright Act, indicated by the "Taverne" license above, 


\section{(Niet) Schudden voor gebruik}

Universiteitsblbliotheek

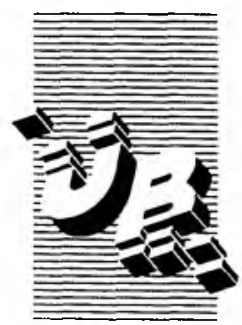

De uitleentermijn verstrijkt op:

\section{DEC. 1995}

Rijksuniversiteit Limburg

Postbus 616

6200 MD Maastricht

Gelieve deze publicatie tijdig te relourneren of (telefonisch) verlenging van de uitleentermijn aan te vragen. 


\title{
(Niet) Schudden voor gebruik
}

\author{
Pleidooi voor een \\ schok-therapie in West-Europa en een \\ geleidelijke overgang in Oost-Europa
}

REDE

uitgesproken bij de benoeming tot

hoogleraar in de Socio-economics of European Labour Markets en tot bijzonder hoogleraar in de Euregionale Economie aan de Rijksuniversiteit Limburg op 31 maart 1994

door

Dr. C. DE NEUBOURG

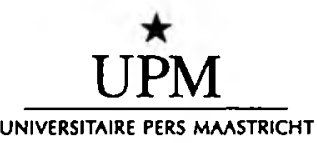




$$
p=125167687
$$

Univarsiceirshbilinthosk

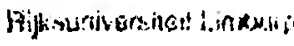


Mijnheer de Gouverneur,

Mijnheer de Burgemeester,

Monsieur Le Recteur,

Mijnbeer de Rector Magnificus,

Dames en Heren,

In de jaren vijftig en zestig van deze eeuw beloofde de economie een invloedrijke wetenschap te worden. In Europese landen zoals België, Frankrijk en Nederland, werden planbureau's opgericht. In Duitsland tekende de Sachverständigenrat de blauwdruk van het Wirtschaftswunder uit, terwijl de Amerikaanse Council of Economic Advisers onder President Kennedy de kunst van het "fine-tunen" definitief onder de knie leek te hebben. In de jaren tachtig echter, dacht President Reagan eraan de Council of Economic Advisers af te schaffen. Michael Boskin, de Voorzitter van de Council onder President Bush moest, naar eigen zeggen, ooit met ontslag dreigen teneinde een gesprek met de President af te dwingen en volgens een recent artikel in de New York Times gebruikt President Clinton de Raad onder meer om het huiswerk van zijn dochter na te kijken'.

Illustreert deze anekdote de huidige plaats van de economie als beleidswetenschap? Als pas-benoemd hoogleraar in die wetenschap hoop je die vraag negatief te kunnen beantwoorden en ik wil de tijd die ons tot de receptie rest, benutten om U hiervan op zijn minst gedeeltelijk trachten te overtuigen.

Anders dan de titel van deze inaugurale rede $U$ zou kunnen doen vermoeden is het geenszins de bedoeling $U$ hierbij te choqueren. Als leerstoelhouder van een ordinariaat dat zich tooit met de omschrijving "The Socio-economics of European Labour Markets", is het evenwel nagenoeg onmogelijk om bij deze gelegenheid niet stil te staan bij de twee schokkendste problemen van de Europese arbeidsmarkten, namelijk de werkloosheid en de werkloosheid; de werkloosheid in West-Europa en die in Centraal- en Oost-Europa.

De Organisatie voor Economische Samenwerking en Ontwikkeling, de OESO schat dat de werkloosheid in West-Europa dit jaar ongeveer 36 miljoen personen of zo'n kleine $12 \%$ van de beroepsbevolking zal treffen. In Centraal- en OostEuropa ontbreken in veel gevallen betrouwbare statistieken, maar het percentage situeert zich tussen de 20 en 40 procent $^{2}$. In beide gevallen is er nood aan een 
beleid dat hierop een antwoord formuleert. Zoals U hopelijk wel uit de titel hebt begrepen wil ik hier pleiten voor een drastische ingreep in de West-Europese economieën en een wat behoedzamer opereren in Centraal- en Oost-Europa. Laat ons thuis, in West-Europa, of beter nog in België en Nederland beginnen.

Over de elementen van de diagnose bestaat in grote lijnen overeenstemming. Dit betekent overigens niet dat over het relatieve gewicht van de verklarende factoren geen diepe meningsverschillen bestaan. De kern van het werkloosheidsprobleem ligt in een tekort aan werkgelegenheid bij een situatie van een onelastisch aanbod van arbeid. Dit werkgelegenheidstekort is op zijn beurt toe te schrijven aan drie grote categorieën van factoren: één, te hoge totale arbeidskosten voor de ondernemingen, twee, een gebrek aan dynamiek binnen het Europese bedrijfsleven en drie een Europa-wijde crisis. Over die laatste caregorie wil ik kort zijn. Slechts zeer weinig analisten geloven dat het werkloosheidsprobleem in de Europese landen niet zou bestaan, als die crisis er niet zou zijn. Met andere woorden, zelfs als we erin zouden slagen om als kleine open economieën succesvol mee te drijven op de golven van de mondiale conjunctuur, dan nog resten ons een paar flinke problemen die om een forse aanpak vragen. Vandaar dat we ons richten op de eerste twee factoren.

De gevolgen van de relatief hoge arbeidskosten zijn op hun beurt in drie categorieën te verdelen. Ten eerste de verplaatsing van bestaande- of de inrichting van nieuwe bedrijvigheden buiten Europa. Dit gevolg, soms omschreven met de ongelukkig etnocentristische term "delocalisatie", is voornamelijk van belang voor de internationaal verhandelbare goederen en voor nieuwe activiteiten. Het tweede gevolg van relatief te hoge arbeidskosten is de vervanging van arbeid door kapitaal of de vervanging van arbeidsintensieve produktieprocessen door minder, maar produktievere arbeid. Dit gebeurt met name bij de produktie van internationaal minder of niet verhandelbare goederen of als het verplaatsen van de bestaande produktie prohibitief hoge kosten met zich mee zou brengen. Relatief hoge arbeidskosten leiden tenslotte en ten derde tot het niet langer produceren van goederen en diensten, althans het niet produceren binnen de observeerbare markteconomie. Samen resulteert dit alles in minder werkgelegenheid en bij een gelijkblijvend arbeidsaanbod, is werkloosheid dan het gevolg.

De volgende vraag is waar die hoge prijs voor arbeid vandaan komt. De totale kosten van arbeid zijn grosso modo opgebouwd uit vier componenten: de nettoloon-kosten (datgene wat de werknemers daadwerkelijk voor hun werk- 
zaamheden ontvangen), de belastingen die daarover betaald dienen te worden, de premies en afdrachten die voor de sociale zekerheid afgedragen worden, en de overige niet-loon-arbeidskosten. Die laatste categorie omvat de kosten voor aanwerving, ontslag, opleiding en vervanging bij ziekte en afwezigheid, algemeen te omschrijven als zoek- en aanpassingskosten. Een werkloosheidsbeleid dat erop gericht is de arbeidskosten te verlagen zal dus op tenminste één van die vier componenten effect dienen te hebben. Wij komen hierop later terug.

Naast relatief te hoge arbeidskosten dient, zoals gezegd, een tweede element in de overwegingen betrokken te worden, namelijk het gebrek aan dynamiek binnen het Europese bedrijfsleven. Twee grote actoren zijn hiervoor verantwoordelijk: de overheid en het management. Over de overheid wordt gezegd dat zij een te groot beslag legt op de middelen waarover een economie beschikt, dat zij door overmatige regelgeving op tal van terreinen de algemene kosten van de produktie op onverantwoorde wijze verhoogt en dat zij daardoor het opstarten of uitbreiden van economische activiteiten ontmoedigt. Over het management wordt gezegd dat de financiële structuur van de ondernemingen, de industriële concentratie en de grote mate van bescherming die kartels en overheid bieden, de ondernemers in onze landen in slaap hebben gewiegd. Zij zijn onvoldoende blootgesteld aan de gezondmakende concurrentie, vertonen te weinig creativiteit, investeren onvoldoende in onderzoek en ontwikkeling, kortom het ontbreekt hen aan Schumpeteriaanse ondernemingszin of "animal spirit". Resultaat: een ondermaatse economische groei met onvoldoende werkgelegenheid.

Het is vanzelfsprekend niet de bedoeling $U$ vanmiddag de contouren van een beleid te presenteren dat al deze factoren omvat, gesteld dat dit al in mijn vermogen zou liggen. Niet zo lang geleden heeft een commissie in opdracht van de Zweedse regering zich aan een dergelijke taak gewaagd: Assar Lindbeck had daarbij de leiding over zeven economen en sociale wetenschappers en schreef een rapport van 200 pagina's met 113 beleidsaanbevelingen en 27 achtergrondpapers $^{3}$. U begrijpt dat mijn opzet bescheidener is.

Ik wil de rest van het West-Europese verhaal toespitsen op een voorstel tot shock-therapie voor het sociale zekerheidsstelsel. Daarvoor heb ik een aantal goede redenen.

Ten eerste is een oratie toch mede een aanleiding om onbeschaamd voor te lezen uit eigen werk voor een publiek dat zich protocollair slechts in beperkte mate kan 
verdedigen. Mocht $U$ op het einde denken dat het met verwijzingen naar het eigen werk wel meevalt, dan kan ik $U$ nu reeds vertellen dat dit valse bescheidenheid lijkt, aangezien $U$ bij de gedrukte tekst zal merken dat het eigen werk vooral in de voetnoten verstopt $\mathrm{zit}^{4}$.

Ten tweede heb ik de laatste jaren in publikaties herhaaldelijk aangegeven dat ik een drastische hervorming van de sociale zekerheidstelsels voorsta, zonder dat ik mij erg precies heb uitgelaten over de richting van een dergelijke hervorming. Ik acht het vanzelfsprekend dat ik aangesproken wordt op die lacune.

Ten derde ben ik van mening dat een hervorming van de sociale zekerheid niet alleen omwille van het werkgelegenheidsargument van belang is. De sociale zekerheid vormt, samen met een gedeelte van de rest van het sociale beleid, de kern van wat we eerder het sociale kapitalisme hebben genoemd ${ }^{5}$. Dit sociale kapitalisme is het resultaat van een specifiek Europese economische en sociale geschiedenis en dient in de kern bewaard te worden. Dit kan echter niet impliceren dat het ook ongewijzigd dient te blijven.

Het is onmogelijk om in het tijdsbestek van deze oratie het hele gamma van kritiek op het huidige stelsel te bespreken. Naast de werkgelegenheidsargumenten zijn de onmogelijke kostenbeheersing, de duidelijke ondoelmatigheid in de vorm van een aantoonbaar Matheus-effect en het bestaan van een groep mensen die onder de armoede-grens leven, de fraudegevoeligheid en de onaangepastheid voor a-typische werknemers en voor onmiskenbare demografische veranderingen, de voornaamste problemen voor het huidige stelsel ${ }^{6}$.

Het behoud van het sociale kapitalisme zal voor een groot stuk afhankelijk zijn van de mate waarin het zich kan aanpassen aan de kritiek en de veranderende omstandigheden. Slagen wij er niet in de aanpassingen te maken dan zal de Nachtwachtsstaat van weleer en de Welvaartsstaat van nu op termijn een Nachtmerriestaat blijken te zijn. Het is mijn stellige overtuiging dat het uitblijven van een hervorming die de vorm wijzigt teneinde de kern te bewaren, het bestaan van het sociale kapitalisme is gevaar brengt en mogelijk zelfs een bedreiging vormt voor de politieke stabiliteit in dit deel van de wereld.

Tenslotte is er natuurlijk het werkgelegenheidsargument waarmee ik dit betoog begonnen ben en waarover ik verder wil uitweiden. 
Het stelsel van de sociale zekerheid, waarmee we gemakshalve zowel de sociale voorzieningen als de sociale verzekeringen bedoelen, heeft op diverse manieren een grote impact op de werkgelegenheid. Het is een sleurel-element in de arbeidskosten, direct door de premieheffing en indirect door zijn invloed op de verstarring op de arbeidsmarkt en de daaraan verbonden hoge zoek- en aanpassingskosten. Ten tweede heeft het een grote impact op de omvang van het beslag dat de overheid op het bruto nationaal produkt legt. Tenslotte wordt de sociale zekerheid door sommigen als schuldige aangewezen voor het algehele gebrek aan dynamiek in onze samenleving. Het hervormen ervan houdt derhalve nogal wat beloften in werkgelegenheidstermen in.

Dat de huidige premieheffing in de sociale zekerheid de bruto-arbeidskosten drastisch verhoogt, hoeft weinig betoog. Het volkomen afschaffen van de premieheffingen en dat gedeelte van de belastingen dat voor de sociale zekerheid wordt gebruikt, zou een directe daling van de arbeidskosten met tientallen procenten betekenen. De sociale zekerheid heeft echter ook een aanzienlijke impact op de verstarring op de arbeidsmarkt. Het beïnvloedt individuen in de keuze voor arbeidsmarktparticiparie en in de keuze voor of regen vrijwel alle vormen van mobiliteit. Het huidige stelsel, in combinatie met een aantal andere sociale wetten, vertoont een aantal serieuze constructiefouten en armoedevallen. Dit betekent dat onder specifieke omstandigheden individuen er in inkomen achteruit gaan als zij een betaalde baan accepteren in plaats van één of meerdere uitkeringen te genieten. In een groter aantal gevallen is er weliswaar geen sprake van achteruitgang, maar is de inkomenswinst bij het accepteren van een baan dermate gering dat slechts een beperkt aantal mensen geprikkeld wordt om die baan te aanvaarden. Het is mij bekend dat het econometrisch onderzoek geen uitsluitsel geeft over de precieze invloed van de uitkeringshoogte op het acceptatie gedrag van bijvoorbeeld werklozen ${ }^{7}$. Het lijkt erop dat een flink gedeelte van de werklozen zelfs een baan accepteert als het geldelijk gewin daarbij gering is ${ }^{8}$. Toch zijn er twee elementen die nopen om hieraan aandacht te besteden. Het eerste is van micro-theoretische aard, het tweede draagt een empirisch karakter.

Wij gaan er als economen van uit dat individuen in vrijwel alle omstandigheden keuzes maken en bij die keuzes is het inkomen, verbonden met de keuze-alternatieven, van groot belang. Welnu, stel dat er geen enkele sociale uitkering van welke vorm dan ook zou bestaan. Ik denk dat de meesten van $U$ het met mij eens zijn dat dit het arbeidsmarktgedrag van velen drastisch zou beïnvloeden. Met andere woorden, onder de extreme omstandigheden van de afwezigheid van een sociaal 
zekerheidsstelsel gedragen personen zich anders dan wanneer er wel een sociaal zekerheidsstelsel bestaat. Het volstaat nu te erkennen dat een gedeelte van die gedragsverandering ook zo bedoeld is, maar het getuigt van gebrek aan fantasie om daarbij te vergeten dat ook een aantal niet bedoelde effecten optreden. Een hervorming van de sociale zekerheid dient er mede op gericht te zijn deze onbedoelde effecten te vermijden.

Diegenen onder $\mathrm{U}$ die denken dat dit type van redenering ontleend is aan het al dan niet verguisde of opgehemelde marginalistische micro-economische denken, wil ik wijzen op een 'Report of the Select Committee of the House of Commons on Labourers' Wages' uit $1824^{\circ}$. Daarin worden drie onbedoelde effecten van de toen geldende loonkosten subsidieregelingen geanalyseerd: arbeiders die een gedeelte van hun loon uit de zogenaamde Poor-rates ontvangen zijn ten eerste minder produktief, zorgen er ten tweede voor sneller te trouwen en meer kinderen te kriigen, want dan stijgt hun uitkering, en dragen tenslotte bij tot, en ik citeer, "the degradation of the character of the labouring class". Voor alle duidelijkheid, we schrijven hier het jaar 1824, het jaar waarin blijkens dezelfde Annual Register, de Koning der Nederlanden op 18 oktober de Staten Generaal in vergadering in Brussel toespreekt "in the Dutch language" om de verloving aan te kondigen van zijn geliefde jongste zoon mer de jongste dochter van zijne Majesteit de Koning van Pruisen. Hetzelfde jaar waarin het totale budget van de overheid ongeveer 26 miljoen gulden bedroeg en een overschot vertoonde van 1.813 .988 gulden en 13 cent: duidelijk andere tijden dus ${ }^{10}$.

Het is bij een keuze-theoretische analyse van belang een onderscheid te maken tussen keuzegedrag onder diverse omstandigheden. Individuen hebben soms meer of minder keuze. Langdurig zieken en arbeidsongeschikten kijken duidelijk tegen andere arbeidsmarktkeuzes aan dan een werkloze schoolverlater. Toch is het nuttig er theoretisch van uit te gaan dat, extreme omstandigheden niet te na gesproken, vrijwel iedereen altijd keuzes heeft, zij her dat die keuzes geconditioneerd zijn door bijvoorbeeld iemands gezondheid. De vraag die zich bij een hervorming van de sociale zekerheid stelt is in hoeverre het stelsel die condities wenst te verdisconteren.

Er hoort ook een empirische observatie bij het verband tussen sociale zekerheid en arbeidsmarktgedrag. Het is opvallend dat de werkloosheid, zowel in hoogte als in duur, zich concentreert bij on- en laaggeschoolden en bij mensen met ongunstig beoordeelde kenmerken. Dit is niet uitsluitend, of zelfs niet in grote 
mate, te wijten aan het keuzegedrag van die individuen, maar vooral aan het feit dat gegeven de geldende totale arbeidskosten waarvan de sociale zekerheidsbijdragen een belangrijk onderdeel vormen, werkgevers niet bereid of in staat zijn om een effectieve vraag naar de arbeid van die groep uit te oefenen. Ervan uitgaande dat het overgrote deel van die groep ook daadwerkelijk aan de slag wil, lijkt het erop dat bij een andere inrichting van de sociale zekerheid aanmerkelijke Pareto-winsten zijn te realiseren; dat met andere woorden beide marktpartijen kunnen winnen of én marktpartij kan winnen zonder dat dit tot verlies bij de andere partij leidt. Mede deze redenering leidt naar voorstellen zoals die onlangs door Drèze en Malinvaud zijn voorgesteld, waarbij aan de onderkant van het loongebouw minder sociale zekerheidsbijdragen dienen betaald te worden ${ }^{11}$. Een hervormde sociale zekerheid dient er op gericht te zijn deze Pareto-effecten te realiseren.

Aan de hand van enkele grafieken wil ik nu de contouren van een nieuw stelsel van sociale zekerheid bespreken, zowel de uitkeringszijde als de financieringszijde komen daarbij aan de orde. De opbouw van het stelsel heb ik niet in de literatuur aangetroffen, al zijn vrijwel alle elementen in een of andere vorm in andere voorstellen terug te vinden. Het stelsel sluit nog het best aan bij de voorstellen van de Wetenschappelijk Raad voor het Regeringsbeleid uit 1985, al verschilt het ook hiervan op enkele belangrijke punten ${ }^{12}$.

De schets van het nieuwe stelsel is noodgedwongen beknopt. Het is handig als $U$ daarbij in gedachte een bierviltje neemt om daarop de grote lijnen van het stelsel uit te tekenen. De omvang van een bierviltje laat echter niet toe alle details te vermelden al hoop ik wel dat uw mentale bierkaartje slechts eenzijdig bedrukt is.

De basis van het stelsel wordt gevormd door een gedeeltelijk basisinkomen waarop iedereen recht heeft (gbi) en dat gefinancierd wordt uit de Belasting op de Toegevoegde Waarde (BTW). De hoogte ervan moet zó vastgesteld worden dat een gedeelte van de basislevensbehoeften eruit gedekt kan worden, zonder dat er sprake is van een sociaal minimum. Om de gedachten te bepalen ga ik nu gemakshalve uit van het gedeeltelijk basisinkomen zoals dat ook in het WRRvoorstel werd gehanteerd namelijk 450 gulden of 8100 Belgische Frank. Het basisinkomen is volledig geïndividualiseerd. Alle ingezetenen of de daaraan gelijkgestelden (ik denk hier met name aan de grensarbeiders en andere personen die in een ander land belasting betalen) ouder dan een bepaalde leeftijd hebben altijd recht op het gbi. Als leeftijdslimiet geldt 18 jaar of jonger als men aan een 
instelling voor hoger onderwijs studeert of als men geen volledig dagonderwijs meer volgt. Het gbi is een bodemvoorziening. Voor werknemers heeft het gedeeltelijk basisinkomen de vorm van een negatieve inkomstenbelasting in casu een belastingvrije som.

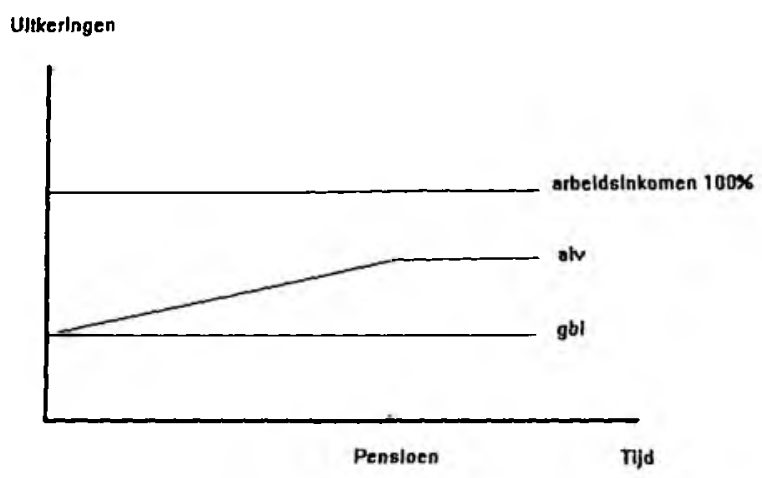

Bovenop deze bodemvoorziening geldt een algemene inkomensderving verzekering (aiv). De aiv wordt betaald uit premieheffing te betalen door alle werknemers en heeft een strikt verzekeringskarakter waarbij de omvang van de uitkering bepaald wordt door de door het individu opgebouwde rechten. De premies worden betaald aan en beheerd door institutionele beleggers die onder controle staan van een onafhankelijk orgaan zoals de sociale verzekeringsbank. De premiehoogte is lineair (loon)inkomensafhankelijk voor iedereen, wordt door de overheid bij wet bepaald; en de fondsen hebben een acceptatieplicht. De fondsen worden beheerd op basis van een kapitalisatiestelsel en volgens strikte actuariële principes beheerd ${ }^{13}$.

De algemene inkomensdervingsverzekering bestaat uit twee delen. De tijdelijke inkomensdervingsverzekering is bestemd voor inkomensderving ten gevolge van werkloosheid en ziekte; de permanente inkomensdervingsverzekering is bestemd voor de opbouw van pensioenrechten. Beide delen worden afzonderlijk geadministreerd maar niet noodzakelijk door een ander fonds beheerd. De verzekerden krijgen bij hun eerste baan een verzekerings- en pensioensnummer dat ze gedurende de hele loopbaan behouden. Verandert een individu van werkgever dan blijft hij of zij de verzekeringsrechten bij hetzelfde fonds verder opbouwen. Overstappen van het ene naar het andere fonds is onder voorwaarden mogelijk, 
maar dient om actuariële redenen niet te worden aangemoedigd. De uitkeringshoogte wordt voor het tijdelijke aiv berekend op basis van het laatst verdiende loon maar heeft een beperkte duur afhankelijk van de opgebouwde rechten. De uitkeringshoogte van de permanente aiv wordt berekend op basis van de opgebouwde rechten en de gemiddelde sterftetabellen. De uitkeringen zijn niet overdraagbaar ook niet na overlijden. Een nader te bepalen periode voor de eerste weken of maanden ziekte dient door de werkgever te worden verzekerd.

De basisuitkering (gbi) is er voor iedereen die aan de voorwaarden voldoet. Verliest een persoon zijn of haar inkomen door werkloosheid of langer durende ziekte dan wordt de totale uitkeringshoogte uitgedrukt als percentage van het laatst verdiende loon bepaald door de som van het gbi en de opgebouwde rechten. Voor iemand die op 18 jarige leefrijd is gaan werken en altijd hetzelfde aantal uren gewerkt heeft, verloopt de uitkeringshoogte ongeveer zoals aangegeven in de grafiek. $\mathrm{Zij}$ is loopbaanafhankelijk en zal hoger worden naarmate de leeftijd hoger wordt.

De duur van de uitkering wordt weergegeven in de volgende grafiek. $\mathrm{Zij}$ blijft $100 \%$ van de uitkering op de eerste dag gedurende 9 maanden, daarna daalt de uitkering tot zij uiteindelijk het niveau van het gedeeltelijk basisinkomen bereikt heeft ${ }^{14}$. De helling van de curve die de daling weergeeft, is afhankelijk van de opgebouwde rechten. Dat wil zeggen dat naarmate een persoon langer gewerkt heeft hij of zij langer recht heeft op een aanvullende uitkering bovenop het gedeeltelijk basisinkomen.

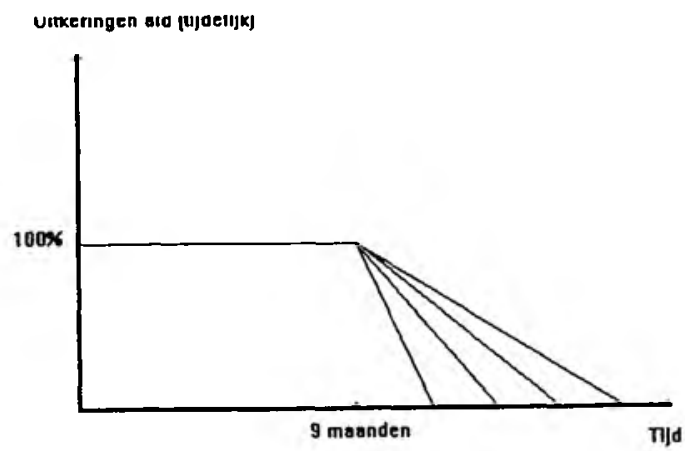


Het stelsel is nu op hoofdlijnen volledig op én punt na. Er zit geen volledige basisvoorziening in die personen waarvan het onredelijk is om te verwachten dat zij ook daadwerkelijk de keuze kunnen maken om zelf in hun levensonderhoud te voorzien. Ik denk hierbij aan drie categorieën: kinderen, vroeg-gehandicapten en blijvend invaliden. Voor hen geldt een apart regime. Kinderen krijgen via hun ouders of verzorgers een kinderbasisinkomen (kbi): deze uitkering vervangt de kinderbijslag. De andere personen, wier vermogen om zelfstandig een inkomen te verwerven op nul moet worden geschat, hebben recht op een verhoogd basisinkomen (vbi) dat hen in staat moet stellen zelfstandig te leven. De precieze hoogte van die basisinkomens dient nader bestudeerd te worden. Dat het overigens niet altijd gemakkelijk zal om te beslissen of iemand tot de categorie van blijvend invaliden hoort is te illustreren aan de hand van het voorbeeld van de verslaafden. Ik denk hierbij niet zozeer aan de drugverslaafden want dat is relatief gesproken een zeer kleine groep, maar aan de alcoholverslaafden. Naar schatting telt Nederland op dit ogenblik zo'n 600.000 alcohol-verslaafden waarvan er slechts $35 \%$ over een inkomen uit arbeid beschikken; dit betekent dat er 390.000 nu aangewezen zijn op een uitkering in het kader van de WAO, de AAW, de WW of de Bijstand ${ }^{15}$. In hoeverre is er voor die groep sprake van het al dan niet hebben van keuzes? In hoeverre is de samenleving in staat en bereid de kosten van de verslaving te dragen en in hoeverre is de samenleving bereid om de sociale gevolgen van verslaafden met enkel een basisuitkering onder ogen te zien? Een specifieke uitwerking van het beleid is op dit punt noodzakelijk, al past dat zoals $\mathrm{U}$ begrijpt niet langer op ons bierviltje.

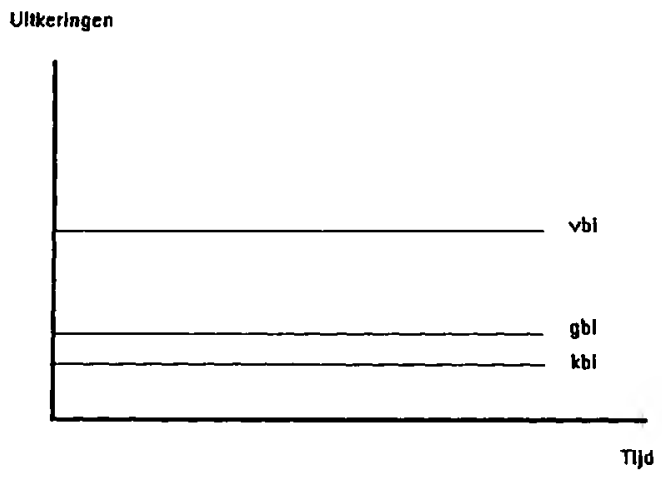


In het tijdsbestek van deze rede passen evenmin alle noodzakelijke verfijningen en randvoorwaarden, al kunnen er drie niet onvermeld blijven. Ten eerste vervangen deze regelingen op straffe van het herintroduceren van armoedevallen, alle inkomenstransfers aan individuen of huishoudens, dus ook huursubsidieregelingen, studiefinanciering en dergelijke. Ten tweede wordt het de CAO-partijen bij wet verboden collectief de overblijvende risico's te dekken of zoals dat in Haags jargon dezer dagen heet "het gat te dichten"16. Pogingen daartoe moeten geïnterpreteerd worden als een complot van insiders tegen outsiders op de arbeidsmarkt, terwijl de overheid door diezelfde insiders verantwoordelijk wordt gehouden voor de ellende die daaruit voortvloeit. Ten derde, het stelsel dient aangevuld te worden met een aantal flankerende maatregelen om individuen bij te staan in het zoeken naar wegen om zelfstandig inkomen te verwerven. Zonder in details te treden wordt hier gedacht aan scholingsbegeleiding, arbeidsmarktbegeleiding, begeleiding bij het opzetten van een eigen bedrijf en dergelijk. Deze diensten worden in mijn visie aangeboden door sociale diensten, OCMW's, arbeidsbureaus, Kamers van Koophandel. Ook voor hen geldt een verbod op het verstrekken van additionele overdrachtsinkomens, maar zij kunnen mensen die daaraan behoefte hebben wel voorzieningen in natura (bijvoorbeeld tijdelijke woonruimte) en kosteloze diensten aanbieden.

Deze laatste voorziening is erg belangrijk. Voor een groot gedeelte van de mensen aan de onderkant van de samenleving geldt dat zelfs een verdubbeling van de huidige uitkeringen hen niet uit de ellende zou halen. Alleen werkelijke bijstand in de vorm van hulpverlening om hen te helpen zelfstandig te overleven en hen te leren keuzes te maken, houdt enige beloften in. Waar meer geld in veel gevallen het subsidiëren van het onverantwoord financieel gedrag of de verslaving betekent en dus uitzichtloos is, kan meer en betere hulpverlening de kwaliteit van het leven van de betrokkenen duurzaam verbeteren.

Het stelsel voor sociale zekerheid zoals ik dat in grote lijnen geschetst heb, heeft een groot aantal voordelen. Als belangrijkste kunnen genoemd worden her feit dat het nieuwe stelsel uiterst eenvoudig te administreren is, geen averse inkomensprikkels geeft, niet fraudegevoelig is, de vraag naar binnenlandse goederen stimuleert, de exportprijzen doet dalen en een drastische daling van de kosten voor arbeid met zich mee brengt. Tenslotte heeft het nieuwe stelsel als voordeel dat het zwaartepunt over de zorg voor de sociale zekerheid gelegd wordt daar waar ze in een moderne democratie ook thuishoort, namelijk bij de overheid en het parlement en niet bij de sociale partners. Dit houdt geen miskenning in van de 
onmiskenbaar positieve rol die de vakbeweging heeft gespeeld bij het totstandkomen van het huidige sociale kapitalisme; het impliceert wel de erkenning van het feit dat de economische realiteit vandaag een andere vorm vereist.

Voor een uitwerking van de voordelen bent $U$ aangewezen op de schriftelijke weergave van deze oratie:

- In vergelijking met de bestaande stelsels is het hier gepresenteerde geheel minder stigmatiserend voor de uitkeringstrekkers, minder gevoelig voor het ontstaan van situaties van moral hazard en armoedevallen, minder fraudegevoelig, minder open voor het Mattheus-effect. Het is daarentegen sexe-neutraler, aanzienlijk eenvoudiger te administreren en (ook daardoor goedkoper) en het legt relatief meer inkomensrisico bij jongere mensen dan bij oudere personen, het biedt meer privacy-bescherming en houdt de pensioenen ook op de zeer lange termijn betaalbaar.

- Het nieuwe stelsel geeft geen negatieve inkomensprikkels aan individuen om voor bepaalde samenlevingsvormen te kiezen, of om voor arbeidmarktsparticipatie te kiezen. In geval van werkloosheid stimuleert het om tijdelijke banen, deeltijdbanen of banen met een loon lager dan wat ze eerst verdienden te accepteren.

- Het nieuwe stelsel laat toe nieuwe elementen te introduceren zoals een verzekering tegen afwezigheid van het werk omwille van ziekte van de kinderen, zoals instap- uitstap systemen, volwassenen-educatie, her-, om- en bij-scholing op latere leefrijd en flexibele pensionering.

- Via de gedeelrelijke financiering uit de BTW leidt het nieuwe stelsel tot een drastische verlaging van de totale arbeidskosten, tot een verhoogde vraag naar binnenlandse goederen, tot goedkopere exportprijzen en tot her laten meebetalen van relatief kapitaalintensieve sectoren aan de maarschappelijke welvaart. De BTW-financiering minimaliseert de mate van afwenteling.

Tot slot van het West-Europese gedeelte van deze rede blijven er nog twee prangende vragen te beantwoorden. Eén is er geen alternatief voor deze toch wat pijnlijke operatie? Twee hoe zit het met de uitvoerbaarheid van de voorgestelde schok-therapie?

Collega Jules Theeuwes heeft onlangs het meest drastische alternatief voor een stelselherziening naar voren gebracht onder de veelzeggende titel "Afschaffing van de welvaartsstaat" $"$. Hij zocht in zijn column naar eigen zeggen alle argumenten bij elkaar om kind én badwater weg te gooien en telde er tien. Hij vermeldt erbij 
dat geen enkele econoom er achter staat, dat geen enkel partijprogramma het vermeldt en dat geen enkele gek het kan volhouden, maar zijn provocatie heeft de charme van de eenvoud en de helderheid van de extreme radikaliteit. Als we echter de keuze hebben tussen volledige amputatie zonder narcose a la Theeuwes en een drastische ingreep onder plaatselijke verdoving, dan ben ik geneigd voor de laatste oplossing te opteren. Velen denken evenwel dat wat plastische chirurgie gecombineerd met een dieet al wonderen zal verrichten. De esthetische ingrepen zijn dan bedoeld om enkele schoonheidsfourjes van het huidige systeem te corrigeren terwijl het dieer de vorm krijgt van een algehele loonmatiging teneinde onze concurrentiekracht op peil te houden.

Het wegwerken van schoonheidsfourjes is moeilijker gebleken dan men aanvankelijk hoopte. Ik hoef $U$ niet te wijzen op de moeizame en nagenoeg mislukte pogingen om de WAO-uitkeringen en het WAO-volume in Nederland te beheersen. Het "grijze gegrom" dat door het land waart omtrent bevriezing van de $\mathrm{AOW}$, is een tweede illustratie van de tegenstand waarop de plastische chirurgen bij hun werk kunnen rekenen. Het effectief politieke verzet van blokkerende minderheden is tot nu toe in de meeste West-Europese landen zeer krachtig gebleken. Waar grote herkenbare groepen kiezers en vakbondsleden gemobiliseerd kunnen worden, zal het moeilijk blijven, zo niet onmogelijk zijn om wijzigingen, laat staan substantiële wijzigingen in het stelsel aan te brengen. Het resultaat is dat een uitkerings- en een volume-beleid zich dus noodzakelijkerwijze zal richten op het niet georganiseerde, en dus het zwakste gedeelte van de samenleving. Is ons echter sinds Bismarck en Beveridge niet voorgehouden dat het bij de inrichting van de sociale zekerheid nu juist om die zwaksten in de samenleving ging ${ }^{18}$ ? Het lijkt er dus op dat de plastische chirurgen hun energie vooral zullen richten op de meest hulpeloze patiënten in plaats van op de "lelijkste". In dat opzicht vormt hun arbeid geen echt alternatief.

Hoe zit het dan met de effectiviteit van het loon-dieetvoorschrift? Zonder te willen suggeren dat loonmatiging helemaal niet moet, zijn de voorspelde resultaten ervan allerminst spectaculair. Het werkloosheidspercentage zou nog vele jaren in dubbele cijfers geschreven worden, als algehele loonmatiging het enige medicijn zal zijn ${ }^{19}$. Uitgaande van de observatie dat het dagloon van een Chinese arbeider ongeveer één honderste bedraagt van dat van een Belgische of Nederlandse arbeider, zouden de lonen wel heel drastisch moeten dalen als "loon" onze enige parel in de concurrentiestrijd zou zijn. Bij dergelijke draconische loonsverlagingen zouden de trottoirs rond het Damrak, de hoeveelheid zich van het leven 
berovende beleggers maar nauwelijks aankunnen. Loonmatiging helpt wel, net zoals ook andere beleidsmaatregelen noodzakelijk zullen blijken naast de hier voorgestelde stelselwijziging, maar ze kunnen een stelselherziening echter niet vervangen.

Toch wil ik hierbij één expliciete uitzondering maken: de arbeidskosten in een gedeelre van de dienstensector kunnen in één klap met ongeveer $20 \%$ verlaagd worden door het afschaffen van de BTW op persoonsgebonden diensten. Ik denk hierbij aan de BTW die $U$ en ik betalen als we onze auto laten repareren of als we de keuken door een beroepsschilder zouden laten schilderen. Er zijn drie goede redenen om het BTW-tarief voor die diensten op nul te stellen. Ten eerste is er het theoretische argument van het cost-disease model zoals het in 1966 door William Baumol en William Bowen zo welsprekend geïntroduceerd werd in hun studie "Performing Arts: the economic dilemma". De kern van het argument is dat de relatieve prijzen van dergelijke diensten noodzakelijkerwijze moeten stijgen omdat er in die sector nauwelijks productiviteitswinsten te realiseren zijn: de arbeidsproductiviteit bij het spelen van een Mozart-kwartet is hedentendage niet hoger dan toen de meester het werk schreef. Die prijsstijgingen te accentueren door er ook nog belasting op te heffen lijkt niet verstandig. Het tweede argument is een principieel argument. Ik vermag niet in te zien waarom ik op de diensten van mijn garagehouder wel BTW moet betalen, maar op de diensten van de bankbediende niet. Tenslotte is er een pragmatisch argument. Het verlagen van de arbeidskosten voor dit type van arbeid dat in veel gevallen laag-en ongeschoold is, zou kunnen betekenen dat de produktie van dergelijke diensten weer verschuiven van de huishoudelijke sector naar de marktsector (dat we met andere woorden, onze keuken niet langer zelf zouden schilderen of zouden moeten schilderen maar ze daadwerkelijk door een beroepsschilder onder handen zouden laten nemen); bij een verschuiving tussen huishoud- en marktsector zouden vele laag- en ongeschoolde werklozen gebaat zijn. Bovendien is een BTW-verlaging aanzienlijk gemakkelijker te realiseren dan het invoeren van de tegoedbonnen voor dat soort diensten zoals dat in het zogenaamde Witboek van Delors voorgesteld wordte ${ }^{20}$.

Laatste prangende West-Europese vraag: hoe zit het met de uitvoerbaarheid van de stelselwijziging zoals hier besproken?

Ik ben wat dat betreft niet hoopvol gestemd. Hierop is waarschijnlijk de uitspraak van toepassing: "de toestand is hopeloos maar niet ernstig"21. De toestand is niet ernstig omdat het systeem nog steeds werkt, zij het krakend. De toestand is 
hopeloos omdat er heel veel belanghebbenden zijn bij de instandhouding van het huidige systeem. Vele van de "stake-holders" zijn machtig omdat ze georganiseerd zijn, gemakkelijk georganiseerd kunnen worden of omdat ze een substantieel gedeelte van de kiezers omvatten, terwijl de echte belanghebbenden, de echte zwakkeren, arm en uitgerangeerd aan de kant staan. In de politieke arena vindt met name het idee van een gedeeltelijk basisinkomen nauwelijks weerklank ${ }^{22}$. Er wordt de indruk gewekt dat het idee een uitvinding is van veertigers die sinds 1968 hun geitenwollen sokken niet hebben uitgetrokken. Niets is minder waar. De eerste ideeën over een basisinkomen in de vorm van een negatieve inkomstenbelasting werden in 1946 in de Verenigde Staten geformuleerd door George Stigler en later in 1962 en 1964 verder uitgewerkt door Milton Friedman en James Tobin. Ondanks deze illustere geschiedenis verwerpen alle grote politieke partijen het idee van een basisinkomen om principiële redenen. Het heilige principe luidt: "geen inkomen zonder werk". In het licht van de vaak jaren durende uitkeringen die mensen ontvangen in het kader van de werkloosheidswetgeving, bijstand en arbeidsongeschiktheidsregelingen, is het een voos en retorisch argument. Onder verwijzing naar dit heilige principe worden velen jarenlang inactief gehouden. De hypocrisie ervan is stuitend en vertoont gelijkenis met het verwerpen van condoomgebruik ter voorkoming van AIDS: onder verwijzing naar het principe van eerbied voor het leven, worden honderdduizenden op het Afrikaanse continent de dood ingejaagd.

Wellicht, dames en heren, is het West-Europa niet anders dan in Oost-Europa: men kan niet verwachten dat de mensen en de organisaties die op dit ogenblik de controle hebben over de instituties, meewerken aan een, voor hen schokkende hervorming. Schoktherapiën roepen immers zelden groot enthousiasme bij de patiënten op.

Ik wil $U$ in deze context wel wijzen om een zekere asymmetrie. De aarzeling waarmee we drastische wijzigingsvoorstellen in onze eigen samenleving begroeten staat in schril contrast met het gemak waarmee we voor Centraal- en Oost-Europa schoktherapiën voorstellen. Deze assymmetrie is niet alleen te verklaren door het ver-van-mijn-bed-argument.

Is het niet merkwaardig dat de economen - die ik beschouw als een beroepsgroep die door beroepsmisvorming vrijwel uitsluitend in termen van marginale wijzigingen kan denken - juist zo'n grote voorstanders waren van een schoktherapie in de Centraal- en Oost-Europese economieën? Hebben we hier te maken met de ultieme wraak op Marx, Engels en Lenin? Wat immers voorgesteld wordt is 
om in één klap hun socialistische revolutie binnenstebuiten te keren door middel van één uitgekiende tegenrevolutie? Ik geloof niet in dergelijke samenzweringstheorieën. De echte redenen zijn onwetendheid en kortzichtigheid.

De onwetendheid spruit voort uit het feit dat we nooit stilgestaan hadden bij de mogelijkheid dat Centraal- en Oost-Europa zo snel en bruusk van hun communistisch geloof zouden vallen. Was ons immers niet voorgehouden dat alle landen van de wereld als domino's één voor één voor het communisme zouden vallen? Wie verwacht dan precies het tegenovergestelde? De tweede bron van onze onwetendheid zijn onze theorieën en beleidservaringen die ons maar weinig ruimte bieden om, eenmaal geconfronteerd met het probleem, ook creatief wat anders te verzinnen dan dat de realiteit zo snel mogelijk op die van onze leerboeken moet gaan lijken.

Onze kortzichtigheid komt voort uit het feit dat we gewend zijn het belang van instituties te verwaarlozen. Toen de bevel-economieën gevallen waren, dachten we op de rokende puinhopen geheel opnieuw te beginnen. We vergaten dat instituties een hardnekkig leven leiden en dat zelfs de val van het communisme niet automatisch impliceert dat ook alle daarmee samenhangende machtstructuren en instituties verdwijnen. De ontkenning daarvan heeft ertoe geleid dat het de beheersers van de oude instituties zijn geweest die zich in eerste instantie verrijkt hebben. Het is de oude nomenclatura die plots ontdekte dat zij onder het kapitalisme nog meer privileges naar zich toe kon halen. Dit keer niet door gebruik te maken van politieke kanalen, maar door gebruik te maken van hun ongelijke positie in de samenleving, de rauwe wetten van de vrije markt en de afwezigheid van wetten en normen omtrent het fatsoenlijk zakendoen in een kapitalistische economie; een tekstboek versie van Durkheim's anomie begrip.

Strenge controle over de geldvoorraad en afschaffen van prijscontroles, handelsbelemmeringen en overheidssubsidies, waren de relarief gemakkelijk te implementeren aanbevelingen van de Westerse adviseurs. De kern van het omschakelingsprogramma is echter de privatizering van de Staatsector en juist met die privatizering liep het in vrijwel alle landen mis. Wij moeten ons daarbij niet laten misleiden door de statistieken die aangeven dat reeds zo'n $20 \%$ van de burgers werkzaam is in de privé-sector. Het overgrote deel van deze mensen werkt immers in privé-bedrijven die al bestonden vóór 1989 en in zeer kleinschalige bedrijfjes. Deze laatste sector is te omschrijven als een "straathandel-zeepbel" die geen basis vormt voor een werkelijke groei naar een kapitalistische economie. De 
zeepbel is niet erg duurzaam en zou bij een eventuele communistische restoratie zeer snel uiteenspatten. Alleen in Polen lijkt zich een relatief succesvol privatiseringsprogramma te voltrekken, maar daarbij dient opgemerkt te worden dat het succes daarvan vooral is toe te schrijven aan het feit dat Polen al een relatief grote privé-sector kende.

In 1989 bestond er een brede consensus over de visie dat het wenselijk was de staatsbedrijven te privatiseren, maar een strategie met betrekking tot die privatisering ontbrak en ontbreekt eigenlijk nog steeds. Sweder van Wijnbergen heeft een maand geleden in zijn oratie aan de Universiteit van Amsterdam de redenen voor het moeizame verloop van de privatisering geanalyseerd ${ }^{23}$. Hij komt tot de conclusie dat het ontbreken van een commercieel banksysteem en de angst voor werkloosheid en de daarmee samenhangende sociale en politieke problemen, daarbij belangrijke obstakels zijn. Impliciet verwijst hij ook naar het ontbreken van een begaanbaar pad naar privatisering door te stellen dat de fiscale moeilijkheden van de meeste landen om een hoge verkoopopbrengst vraagt, maar dat de meeste bedrijven bij verkoop niets of bijna niets zouden opbrengen.

Er staan nu nog twee mogelijkheden open: liquidatie van de meeste staatsbedrijven om verdere schade te voorkomen of het uitwerken van een privatizeringsstrategie. Collega van Wijnbergen heeft overtuigend gepleit tegen liquidatie, ik hoef dat hier niet over te doen. Het voornaamste argument is dat een snel invoeren van een op Westerse leest geschoeide faillisementswetgeving ertoe zou leiden dat in veel gevallen potentieel winstgevende ondernemingen zouden sluiten. Rest ons het uitwerken van een privatiseringsstrategie. Daartoe wil ik hier een aanzet geven.

De basis van de strategie wordt gevormd door de bestaande situatie die economische, maar ook sociale kenmerken heeft.

De economische realiteit is dat de staatsondernemingen niet alleen verlies maken maar dat deze verliezen zeer snel in omvang groeien en geaccumuleerd worden. De verliezen worden uit vijf bronnen gefinancierd: rechtstreekse staatsubsidies, het niet betalen van belastingen, sociale zekerheidsbijdragen en interesten, het niet betalen van lonen, het niet betalen van leveranciers en het opnemen van leningen bij de staatsbanken. Deze situatie is onhoudbaar. Het niet betalen van belastingen en dergelijke en her incasseren van rechtstreekse staatsubsidies brengt het overheidsbudget elke dag dichter bij een fiscale ramp. Het niet betalen van lonen brengt de sociale stabiliteit in gevaar. Het niet betalen van leveranciers brengt de economie in een neerwaartse spiraal van niet gedekte verliezen. Het 
opnemen van bankkredieten bij staatsbanken tenslotte is een verdoken vorm van staatssubsidies en verhindert het tot stand komen van een gezonde commerciële banksector.

De sociale realiteit is dat de managers van de staatsbedrijven geen enkele prikkel hebben hun ondernemingen ook beter te runnen. Hun gebrek aan financiële discipline wordt gedekt door de mogelijkheden om de verliezen op onverantwoorde wijze te financieren. Daarnaast missen de managers de noodzakelijke kennis, vaardigheden en ervaring om hun ondernemingen binnen een markteconomie te runnen. Die kennis is evenmin aanwezig bij anderen. Ook de vakbewegingen bieden geen grote hulp op dit terrein. $\mathrm{Zij}$ zijn in de meeste gevallen sterk centralistisch georiënteerd en hebben eerder ideologische dan praktische bekommernissen. Er is geen commerciële banksector die enige hulp kan bieden. Kortom de netwerken, formeel en informeel, die ook in onze economieën van cruciaal belang zijn, ontbreken ten enen male. Er zijn natuurlijk wel netwerken, maar die zijn in een markteconomie niet doelmatig en in de meeste gevallen gecorrumpeerd daar ze opgebouwd zijn tijdens het vorige regime.

Een privatiseringsstrategie hoort mijn insziens nu met deze realiteiten rekening te houden. Het eerste wat er moet gebeuren is het opleggen van een strenge financieringsdiscipline aan de staatsbedrijven. Dit kan echter niet schoksgewijs gebeuren want dan komt het neer op een de facto liquidatie van de ondernemingen. Omwille van de overheidsbudgetten dient het echter wel snel en beslist te geschieden. Voor het opleggen van een financieringsdiscipline dient ten tweede een vorm worden gekozen die a. de ondernemingen een kans op overleven biedt en $b$. in snel tempo de verantwoordelijken de kennis, vaardigheden en netwerken bijbrengt die nodig zijn om in een marktsituatie te overleven. Aan deze voorwaarden kan wellicht voldaan worden als de volgende vorm wordt gekozen.

Voor elke staatsonderneming stelt de overheid een pad voor dat op een termijn van, zeg 5 jaar alle vormen van transfers uit het budget tot nul reduceert, waarbij per jaar wordt aangegeven hoe groot de transfers nog kunnen zijn. De onderneming dient gegeven dit pad aan te geven wat dit voor de onderneming betekent. In bijna alle gevallen is de ontbinding van de grote conglomeraten in afzonderlijke profit-units noodzakelijk. In sommige gevallen zal dit betekenen dat alsnog tot liquidatie wordt besloten. In andere gevallen zal het mogelijk zijn een rationaliseringsstrategie voor de onderneming uit te werken. In een enkel geval zal verkoop of gedeeltelijke verkoop of een of andere vorm van joint venture met een buitenlandse onderneming tot de mogelijkheden behoren. Eventuele Westerse 
overname-kandidaten of kandidaten voor joint-ventures zouden bij deze overgangsfase betrokken kunnen worden. De overheid kan, afhankelijk van de aard van het bedrijf en/of van de kenmerken van de regio waarin het bedrijf zich bevindt, het tempo van de afbouw van transfers differentiëren, maar nooit langer laten duren dan 5 jaar.

Daarnaast en even belangrijk, geeft de overheid voor elk bedrijf aan, dat een gedeelte van de niet langer toegestane transfers, gedurende een welbepaalde periode en volgens een strikt pad, ter beschikking wordt gesteld van een regionale raad. Die raad dient samen met de ondernemingsleiding, de vakbonden, de lokale bestuurders en een vertegenwoordigers van een commerciële bank, een aanpassingsstrategie te bepalen. Dit wil zeggen dat zij dienen te bepalen hoe zij de fondsen zullen gebruiken teneinde de gevolgen van de herstructurering op te vangen. Die lokale of regionale raad dient daarbij autonoom te kunnen besluiten en onbeperkt te zijn in zijn mogelijkheden. De raden kunnen besluiten dat herscholing in sommige gevallen het belangrijkste is, maar ook dat zij het geld zullen gebruiken om nieuwe kleinere ondernemingen te helpen starten. Alles wat bijdraagt tot het initiëren van nieuwe activiteiten in de marktsector of tot het voorbereiden van de beroepsbevolking om binnen de marktsector te overleven, is toegestaan, met uitzondering van inkomenstransfers aan wie dan ook. Maar ook hier gelden twee belangrijke principes namelijk absolute begrotingsdiscipline en een strikt tijdspad waarbij duidelijk is tegen welk tempo en op welk tijdstip de inkomstenstroom ophoudt. De tijdshorizon dient niet langer te zijn dan 5 jaar, maar wel van te voren duidelijk te zijn. De hulp van Westerse landen en internationale organisaties zou voor een belangrijk gedeelte gericht kunnen worden naar het voorzien van technische assistentie, zowel voor het management van de staats-ondernemingen als voor de bestuurders van de regionale raden. Westerse experts zullen dan eerder assisteren bij de dagdagelijkse problemen van de herstructurering, dan door het schrijven van aanbevelingen die ze niet zelf hoeven te implementeren.

De voorgestelde privatiseringsstrategie heeft het nadeel dat het overheidsbudget nog enkele jaren onder druk blijft staan, maar dit is mijns inziens te verkiezen boven een situatie waarbij een schoksgewijze stopzetting van alle transfers leidt tot een ineenstorting van de bestaande economische bedrijvigheid. Als dit zou gebeuren zou niet alleen de bestaande industriële basis volledig ontmanteld worden, maar bovendien is het zeer de vraag of de werkloosheid en de armoede die ervan het gevolg zouden zijn, door de bevolking zouden aanvaard worden. 
Het wegvallen van het laatste restje van sociale en politieke legitimiteit van de hervormingen leidt of naar chaos of naar een communistische restauratie. De recente verkiezingsuitslagen in enkele landen stemmen wat dat laatste betreft niet echt hoopvol. In een recent artikel in Foreign Affairs stelde Joeri Afanasjev, Rector van Russische staatsuniversiteit voor menswetenschappen en een van de leiders van de democratische oppositie, dat het in Rusland misschien al te laat is en dat de hervormingen alleen nog in de retoriek van de machtshebbers bestaan; werkelijke hervormingen zier hij niet meer plaatsvinden ${ }^{24}$.

Het voordeel van een dergelijke herstructureringsstrategie is dat de bestaande bedrijven de kans krijgen om tot een functionerend bedrijf in de marktsector uit te groeien. Zo wordt nodeloze kapitaalvernietiging vermeden. Het feit dat bij het proces veel mensen betrokken worden houdt zekere risico's in. Het vooruitzicht echter dat heel veel mensen leren opereren in een voor hen volstrekt nieuwe marktsituatie, weegt ruimschoots op tegen die risico's en tegen de inertie en het fatalisme dat zo kenmerkend is voor de huidige situatie. Over de markt-ervaring van de inwoners van Centraal- en Oost-Europa moeten we niet al te veel illusies koesteren. Bijna vijftig jaar communistisch regime heeft geresulteerd in een gesocialiseerde onvermogen om in markttermen te denken of om op markten actief te zijn. Voor Rusland kan hierbij zelfs niet worden teruggegrepen op enige verre traditie. Wie dat vergeten is doet er goed aan Gogol en Toergeniev te herlezen.

Vanzelfsprekend dient er meer te gebeuren dan het volgen van de hier beschreven privatiseringsstrategie. Een pro-actief arbeidsmarktbeleid, macro-economische stabiliseringsprogramma's en het inrichten van een deugdelijke sociale zekerheid staan daarbij centraal. De tijd laat niet toe er nu op in te gaan. Voor één punt wil ik echter een uitzondering maken en dat betreft het handelsbeleid van de Europese Unie. Het is ronduit schandelijk hoe onze landen zich in handelspolitieke termen opstellen ten opzichte van Midden- en Oost-Europa. Terwijl de retoriek van de steun aan de hervormingen blijft ronken in Brussel, Den Haag, Parijs en London, houden we onze grenzen voor hun produkten pordichr. In sommige gevallen hebben we zelfs extra handelsbelemmeringen opgeworpen en als klap op de vuurpijl sturen we zwaargesubsidieerde landbouwprodukten naar die landen zodat een pakje Nederlandse of Belgische boter er al gauw goedkoper is dan de plaatselijk geproduceerde boter. Tegen zoveel kortzichtig eigenbelang is geen enkel goedbedoeld steunprogramma opgewassen. Wat we met gulle hand geven 
wordt dubbel teruggepakt en ondertussen helpen we wat er rest aan lokale economie naar de bliksem. Het wordt tijd dat we ons over zoveel dubbelhartigheid serieus bezinnen.

Zeer gewaardeerde toehoorders, de voorstellen tot de hervorming van de sociale zekerheid voor West-Europa, noch de privatiseringsstrategie voor Oost-Europa beschouw ik als het ei van Columbus. Wie oud genoeg is om oraties te houden, dient ook te weten dat Columbus nooit eieren heeft gelegd, laat staan nagelaten. Ik hoop niettemin een zinvolle bijdrage te hebben geleverd aan twee discussies die naar mijn oordeel op dit ogenblik tot de kern van de "socio-economics of European labour markets" behoren. Deze kern heeft geen zuiver economisch karakter, maar ook een onmiskenbare sociale en politieke dimensie. Dat de politieke stabiliteit in gevaar is, als we er niet in slagen de werkloosheidsproblemen in Midden- en Oost-Europa op te lossen, vindt U wellicht allemaal vanzelfsprekend. In navolging van socioloog Alain Touraine in zijn onlangs gepubliceerde boek "Qu'est-ce que la démocratie?", wil ik ook aangeven dat het oplossen van het werkloosheid- en sociale zekerheidsvraagstuk voor onze democratieën wel eens van levensbelang zou kunnen zijn. De gekozen oplossingen dienen aan de ene kant de individuele keuzes van burgers zo maximaal mogelijk te respecteren en anderzijds vorm te geven aan een samenleving die door de meerderheid als rechtvaardig beschouwd wordt. I $\mathrm{k}$ heb de stellige indruk dat veel van het sociaal en economische beleid nu niet aan die twee fundamentele vereisten voldoet; dat veel mensen het gevoel hebben dat de keuzes niet door henzelf maar door oligarchiën gemaakt worden en dat de uitkomsten lang niet altijd als rechtvaardig gepercipieerd worden.

\section{DANKWOORD}

Aan het eind van mijn oratie gekomen, wil ik in de lijn van de traditie enkele welgemeende woorden van dank uitspreken.

Hooggeleerde Maddison, Dear Angus,

You directed my interest towards international comparative research and as you can judge from my present work, both in research and teaching, your influence has been decisive for my career. The standards you set for my Phd-work were high and I am very grateful that you taught me, more than anyone else, how 
to stick to these scholarly standards without letting striving for perfection inhibit publication according to certain deadlines. I remember one day when we discussed the final draft of my thesis in a road-restaurant near Sint-Niklaas. You proposed to rearrange the book by reducing the number chapters drastically and by turning chapter 5 in chapter 1 . I referred to the General Theory to defend my proposition but you replied that, and I quote: "You can do a better job than Keynes". I finally rearranged the book the way you proposed. However much I learned from your academic advices, your influence on other aspects of my professional life has been also important. You showed me that running a vakgroep is a game with hard rules and my naivety in this respect could be damaging for myself as well as for other people. But if I have to single out one thing that I learned from you, it would be the fact you showed me how beneficial the mix of scholarly discipline with academic anarchism and non-conformism is in your own work.

Zeer gewaardeerde leermeesters, beste collega's, beste vrienden,

De lijst met mensen die op beslissende wijze hebben bijgedragen aan mijn academische vorming is dermate lang, dat er mij bij de voorbereiding van deze rede twijfels bekropen aangaande mijn eigen inbreng. Op het gevaar af sommige mensen te vergeten wil ik er toch een aantal met name noemen. Allereerst Professor Deleeck die mij niet alleen van bij mijn prille begin als student op de universiteit, onderwezen heeft in de sociale economie, die niet alleen, op de hem bekende indringende wijze, mijn aandacht gewekt heeft voor de problematiek van de sociale zekerheid, maar die er bovenal in 1975, dubbelgevouwen op de achterbank van onze Renault 4, op aangedrongen heeft dat ik mijn weinig succesvolle carrière als Brusselse ambtenaar na minder dan een jaar zou beëindigen, om aan de Economische Faculteit in Groningen te gaan werken. Met Herman Deleeck moet ik vele andere van mijn leermeesters bedanken, Louis Van Bladel, Coen Boey en wijlen Wim Thijs die mijn inwijdden in fascinerende wereld van de filosofie; Karel Van Isacker, Herman van der Wee en Herman Daems die hun enthousiasme voor de geschiedenis op mij overgedragen hebben. Gaston Eyskens die mij als Eerste Minister en professor leerde dat een overheidsbudget niet alleen volgens de leer der publieke financiën tot stand komt; Mark Eyskens die mij het belang van de micro-economische theorie bijbracht en Theo Peeters die hetzelfde deed met de internationale economische theorie. Eenmaal aan de universiteit van Groningen werkzaam bleek mijn vorming geenszins voltooid, zij het dat ze ander karakter kreeg. Ik denk met heel veel academisch en sociaal genoegen terug aan de vakgroep Sociologische Economie waar ik in de 
personen van wijlen Cees de Galan, Iwan Gadourek, Tjerk Huppes, Eric Bax, Rik Derveld en Eddy Szirmai een vriendenclub aantrof die bereid was mijn onervarenheid met zoveel liefde te vergoelijken dat ik er mij nog over verbaas. $\mathrm{Zij}$ gaven mij, later samen met de collega's van de sectie geschiedenis, de kans om al doende te leren. Van mijn eindeloze discussies met Ed Szirmai, die sindsdien niet opgehouden zijn, heb ik meer geleerd dan wat ik kan samenvatten in enkele zinnen. Ook de andere collega's van de faculteit hebben me heel wat bijgebracht en met name denk ik aan Simon Kuipers, Piet Keyser en vooral aan Joan Muysken, die op een goede dag vond dat we maar eens samen onderzoek moesten doen. I $\mathrm{k}$ ben hem tot de dag van vandaag dankbaar voor deze samenwerking die we in Maastricht voortgezet hebben.

Ook van mijn medestudenten heb ik altijd veel geleerd en speciaal wil ik hier vermelden de leden van de inmiddels ter ziele gegane "Keetje Tippel - groep", die, anders dan de naam doet vermoeden, vorm gaf aan onze gezamenlijke academische interesse in de sociale en economische geschiedenis, maar waarin we finaal besloten dat we toch meer gecharmeerd waren van Paul Lafargue's "Recht op Luiheid". Naar al de mensen die hier genoemd heb gaat mijn oprechte dank uit.

Een heel speciaal woord van dank wil ook richten aan mijn ouders. Hun bijdrage aan mijn vorming is in geen woorden te vatten en toch wil ik het proberen door hen te bedanken voor drie specifieke dingen. Ten eerste voor het intellectuele klimaat thuis waarbij nieuwsgierig zijn, lezen en studeren vanzelfsprekendheden waren. Ten tweede voor de wijsheid dat niets in het leven aangenaam is, als het gespeend is van een relativerend gevoel voor humor. En ten derde voor de talrijke discussies aan de tafel van een middelgroot gezin, waaraan ook vaak een aantal vrienden aanzaten. Met name deze discussies hebben me geleerd dat je in een storm van verhalen en redeneringen, soms vrij luid moet praten om gehoord te worden.

Tenslotte wil ik me richten tot de mensen waarmee ik hier in Maastricht en in Luik samenwerk.

Dames en Heren van de Kamers van Koophandel en Fabrieken voor Maastricht en Omstreken en voor de Mijnstreek,

Voor de beslissing om een bijzondere leerstoel in de Euregionale economie in te stellen is de Faculteit der Economische Wetenschappen U zeer erkentelijk. Minder dan twee jaar na de instelling ervan kunnen we nu reeds terugblikken op 
een aantal kleinere afgeronde onderzoeken. Zeer binnenkort starten we met twee grote onderzoeken en een groot aantal projecten en projectjes worden voorbereid. De belangstelling die voor deze activiteiten bestaan vanuit de Gemeente Maastricht, de Provincie Limburg, de Euregionale grenskamers, en andere regionale organisaties, illustreren dat de leerstoel zeker in een behoefte voorziet. Als leerstoelhouder hoop ik constructief te kunnen meebouwen aan een grensoverschrijdende verstandhouding tussen alle betrokken partijen. Ik dank $U$ voor het in mij gestelde vertrouwen.

Dames en Heren van de Faculteit der Economische Wetenschappen van de Rijksuniversiteit Limburg te Maastricht,

De tijd die verlopen is tussen het uitspreken van deze oratie en de dag dat ik hier in dienst ben gekomen, brengt met zich mee dat $U$ ondertussen wel weet wat voor vlees $U$ in de toga heeft. Dat ik bijna nooit met tegenzin naar dit gebouw kom is in belangrijke mate aan $U$ te danken. Ik ben $U$ zeer erkentelijk voor de vriendschappen, de goede verstandhouding en het vertrouwen dat $U$ mij schenkt. De ruimte die $U$ mij geeft om soms op onorthodoxe wijze mijn taken in te vullen waardeer ik voluit. Ik denk ook met dankbaarheid aan de vrolijkheid en de efficiëntie van de ondersteunende staf; veel van wat de wetenschappelijke staf onderneemt is alleen maar mogelijk doordat de secretaresses, de mensen van bureau onderwijs, de examenadministratie, het bureau internationalisering, enzovoort het ook mogelijk maken. Ik wil het voornemen uitspreken om als kapitein van het kleinste en nieuwste schuitje van de vloot, een loyaal onderdeel van de facultaire flottielje te blijven, bij gunstige en ongunstige winden. Het belangrijkste is echter dat er een frisse wind blijft waaien en het moet mij van het hart dat ik mij daarover de laatste tijd wat zorgen begin te maken. Te oordelen naar de lange termijn begroting en het gezicht dat het faculteitsbestuur daarbij vertoont, is het bestuur het enige dat aan deze faculteit nog probleemgestuurd is. Ik vertrouw erop dat we er in de nabije toekomst in slagen de opkomende somberheid van ons af te schudden.

Mesdames, Messieurs de la Faculté d'Economie, de Gestion et des Sciences Sociales de l' Université de Liege,

Tout Belge que je suis, mon accent n'est pas le votre, et je fais figure d'étranger parmi vous. Mais chaque semaine, je suis séduit par votre hospitalité et votre accueil. J' espere qu'au cours des années a venir, nous aurons l'occasion d'apprendre a mieux nous connaitre et d'établir une collaboration fructueuse. 
Dames en Heren studenten van de Economische Faculteit te Maastricht,

Wetenschap en studeren zijn leuke activiteiten als er naast de nodige zelf-discipline ook en flinke dosis eigengereidheid, non-conformisme, durf, gedrevenheid en begeestering aan te pas komt. Die kwaliteiten vind ik vaak bij jullie en in dat opzicht is het meestal ook een waar genoegen jullie te begeleiden. Ik geniet van jullie enthousiasme en jullie inzet en wil die de volgende jaren blijven stimuleren.

Mesdames, Messieurs étudiants a l' Université de Liege,

Mon experience parmi vous est encore limitée. Pourtant je puis déja dire sans exagérer que je me rends avec un réel plaisir au Sart-Timan pour y donner cours. Votre modestie pas entierement fustifiée me surprend souvent, et je veux m'efforcer dans les années qui viennent de contribuer utilement a votre formation, ainsi qu' au développement et a la valorisation de vos qualités professionnelles.

Ladies and Gentlemen students in International Economic Studies,

I promised you an adventure when you started your study in our new graduate programme. I am very glad that you were prepared to take the risk of being adventurous. Be sure that $I$, myself and the staff of the graduate programme are dedicated to turn our journey into a success.

Beste vrienden, vroeger vonden wij dat hoogleraren niet zelden gekenmerkt werden door een speciale vorm van contactgestoordheid en zelfs een lichte neiging tot autisme vertoonden. Alhoewel met de jaren onze oordelen wat milder zijn geworden, wil ik $U$ toch oproepen mij tijdig te corrigeren mochten de eerste symptomen van dit syndroom zich bij mij aandienen.

Zeer gewaardeerde toehoorders,

In deze tijden waarin het lang niet duidelijk wanneer we iets dienen te schudden voor gebruik, wil ik afsluiten met een bijna-zekerheid. Het is vrijwel zeker dat het nog tenminste zeven jaar zal duren vooraleer mijn dochter economie-huiswerk zal moeten maken. Bovendien verwacht ik niet dat zij daarbij mijn assistentie nodig zal hebben of zal willen. Ik zal mij dus de volgende jaren met andere werkzaamheden bezig moeten houden.

Ik heb gezegd. 


\section{REFERENTIES}

1. Geciteerd in Bohets, J., De frustraties van de ekonoom, De Standaard, 5 maart 1994.

2. In Bulgarije heb ik onlangs op basis van Arbeidskrachtentellingen de werkloosheid geschat op circa 21 percent; het werkloosheidspercentage in de Neue Bundesländer wordt op circa 40 percent geschat.

3. Assar Lindbeck, et. al., Options for economic and politic reform in Sweden, Economic policy, october 1993, p. 219 - 264.

4. Kerckhoffs, C., Neubourg, C. de, en Palm, F., The determinants of unemployment and jobsearch duration in the Netherlands, De Economist 142, 1994, pp. 21-42, Kluwer Academic Publishers.

Neubourg, C. de, De Belgische en Nederlandse arbeidsmarkt in een internationaal vergelijkend perspectief, Maandschrift Economie, 1993.

Muysken, J. and Neubourg, C. de, (1993), Hoe sociaal is de EG? Het sociale beleid, in: J. Muysken en L. Soete (eds.), Maastricht 1991 kritisch beschouwd, Preadviezen 1993, Koninklijke Vereniging voor de Staathuishoudkunde, Uitgeverij Lemma, Utrecht, 1993, pp.27-57.

Neubourg, C. de, The choice was ours: unemployment policy in an international comparative perspective, in C. Verhaar (ed.), On the Mysteries of Unemployment, Kluwer, Deventer, 1992, p.317-333.

Neubourg, C. de. The Art of Full Employment, North Holland, AmsterdamNew York, 1991.

Neubourg, C. de, Job libido and the culture of unemployment; an essay in sociological economics, in R. Coughlin (ed.) Morality, Rationality and Efficiency: New Perspectives on Socio-Economics, M.E. Sharp, New York, 1991; pp.61-78. 
5. Muysken, J. and Neubourg, C. de, (1993), Hoe sociaal is de EG? Het sociale beleid, in: J. Muysken en L. Soete (eds.), Maastricht 1991 kritisch beschouwd, Preadviezen 1993, Koninklijke Vereniging voor de Staatshuishoudkunde, Uitgeverij Lemma, Utrecht, 1993, pp.27-57.

6. zie voor meer details L.Geleijnse, J.C. Vrooman en R.J.A. Muffels, Tussen ministelsel en participatiemodel; een verkennende studie naar stelselvarianten in de sociale zekerheid, Sociaal en Cultureel Planbureau, Den Haag, december 1993.

7. zie voor details C. de Neubourg, Unemployment and Labour market flexibility: the Netherlands, Ilo, Geneva, 1990.

8. zie "the world according to Jantje van Leyden" in Coughlin (ed.)

9. The anual register or a view of the history, Politics and literature of the year 1824, London, Baldwin, Cradock and Joy, 1825, Appendix to chronicle; public documents, p.48.

10. ibidem, chapter XI, p. 160.

11. Jacques Drèze and Edmond Malinvaud, Growth and employment; the scope of an european initiative, Paper presented at the Annual Meeting of the European Economic Association, Helsinki, september 1993.

12. Wetenschappelijke Raad voor het Regeringsbeleid, Guarantees for security, no. 33, The Hague, Government Publishing Office, 1985.

13. Er bestaat een gevaar dat de aldus ingestelde fondsen veel macht krijgen in de economie in de zin dat zij zullen beschikken over grote sommen te beleggen middelen. Zij zouden daardoor in staat kunnen zijn de economie te sturen op een wijze die strijdig is met het algemeen belang. Het lijkt wenselijk deze mogelijke machtsconcentratie tegen te gaan door diverse kleinere fondsen in het leven te roepen.

14. De grens van 9 maanden werd gekozen omdat uit empirisch onderzoek blijkt dat de tewerkstellingskans na 9 maanden drastisch begint te dalen. Het ligt voor de hand om vanaf dat tijdstip een extra prikkel in het systeem in te bouwen teneinde werklozen een signaal te geven dat een actiever zoekgedrag gewenst is teneinde de dalende kans op werkgelegenheid te compenseren. Voor zover het dalen van de tewerkstellingskans toe te schrijven zou zijn aan 
een verminderend zoekgedrag, is deze prikkel zeker op zijn plaats. Zie C. Kerchoffs, C. de Neubourg en F. Palm, The determinants of unemployment and jobsearch duration in the Neterlands, De Economist, 1994.

15. Cijfers uit her Jaarverslag CAD, Limburg, 1993.

16. Personen mogen zich individueel privaat bijverzekeren.

17. Theeuwes J.J.M., Afschaffing van de welvaartsstaat, Economisch Statistische Berichten, 23 februari 1994, nr. 3950, jaargang 79, p. 167.

18. En nogmaals zou de welvaartsstaat eerder het profijt en de macht van de middengroepen dienen dan tegemoet te komen aan de noden van de allerarmsten. Zie ook A. de Swaan, Incare of the State: health care, education and welfare in Europe and the USA in the Modern Era, 1988.

19. Daarbij dient verder opgemerkt te worden dat de loonkosten slechts een beperkt gedeelte van de totale productiekosten omvatten. Uit recente gegevens van het Nederlands Verbond van Ondernemingen blijkt dat slechts 1\% van de exportbedrijven zegt last te hebben van de hoge loonkosten; vooral midden- en klein-bedrijf zegt in iets hogere mate daarvan last te hebben. Internationaal gesproken hangen hoge lonen samen met een hoge ontwikkelingsgraad; lonen in de nieuw geïndustrialiseerde landen of in ontwikelingslanden zullen ook verder stijgen naarmate de ontwikkeling daar zal toenemen.

20. J. Delors, Witboek, Growth, competitiveness, employment: the challenges and ways forward into the $21 \mathrm{st}$ century, Commission of the European Communities, Brussels, 5 December 1993.

21. Paul Watzlawick, The situation is hopeless, but so serious, in Nederlands vertaald als, Geluk is ook niet alles, Van Loghum Slaterus, Deventer, 1983.

22. zie voor een overzicht: J.M. Roebroek, E. Hogenboom, Basisinkomen alternatieve uitkering of nieuw paradigma? 's-Gravenhage, Ministerie van Sociale Zaken en Werkgelegenheid, 1990.

23. S. van Wijnbergen, Oost Europa vijf jaar na de val, Oratie, Universiteit van Amsterdam, 18 februari 1994.

24. Youri Afanasjev, in Foreign Affairs, 1993, vertaald gepubliceerd in de Volkskrant, 12 maart 1994, p. 16. 
(Ne pas) Agiter avant l'emploi 


\title{
(Ne pas) Agiter avant l'emploi
}

\section{Plaidoyer en faveur}

d'une therapie de choc en Europe de l'Ouest et d'une transition graduelle en Europe de l'Est

\author{
Leçon inaugurale \\ par \\ Chris de Neubourg \\ Rijksuniversiteit Limburg Maastricht \\ $\&$ \\ Université de Liège
}

prononcée à Maastricht (en néerlandais) le 31 mars 1994 
Monsieur le Gouverneur,

Monsieur le Bourgmestre,

Messieurs les Recteurs,

Mesdames et Messieurs,

Dans les années cinquante et soixante les sciences économiques semblaient promises à un grand avenir. Dans des pays européens tels que la Belgique, la France ou les Pays-Bas, on établissait des bureaux du plan. En Allemagne (BRD), le "Sachverständigenrat" ébauchait le "Wirtschaftwunder", tandis qu'aux EtatsUnis, sous le Président Kennedy, le "Council of Economic Advisers" semblait avoir définitivement maîtrisé l'art du "fine tuning". Et pourtant, dans les années quatre-vingt, le Président Reagan envisageait d'abroger le "Council of Economic Advisers". (La raison n'en était d'ailleurs pas que le "fine tuning" fût devenu un jeu d'enfants au point de rendre les experts superflus.) Michael Boskin, qui était à la tête du "Council" sous le Président Bush, raconte avoir dû un jour menacer de démissionner afin d'obtenir une entrevue avec le Président. Mieux encore, selon un article récent du New York Times, le Président Clinton trouve le "Council" utile pour, entre autres choses, corriger les devoirs de sa fille. ${ }^{1}$

Ces anecdotes illustrent-elles l'avenir de la science économique en tant que science politique? Frâichement nommé professeur en sciences économiques, l'on espérerait bien sûr qu'il serait possible de répondre à cette question par la négative. Aussi, je compte bien mettre à profit le temps qui nous reste avant la réception pour tenter de vous en convaincre, ne fut-ce que partiellement.

Contrairement à ce que le titre de cette leçon inaugurale a pu vous faire penser, mon intention n'est pas de vous choquer. Mais occupant une chaire intitulée "The Socio economics of European Labour Markets", je puis difficilement contourner à cette occasion les deux problèmes les plus choquants des marchés du travail européens, à savoir, le chômage et le chômage: celui de l'Europe occidentale, et celui de l'Europe centrale et orientale.

L'Organisation pour la Coopération et le Développement Economiques (OCDE) estime que le chômage touchera cette année en Europe occidentale environ 36 millions de personnes, soit quelque $12 \%$ de la population professionnelle. En Europe centrale et orientale les statistiques fiables font défaut, mais le pourcentage se situe sans doute entre 20 et $40 \%{ }^{2}$ Tant à l'Est qu'à l'Ouest, le besoin de 
formuler la politique qui résoudra le problème reste cruellement présent. Comme vous l'aurez sans doute déduit du titre de cette leçon, je veux plaider ici pour des mesures énergiques dans les économies de l'Ouest, et pour une approche plus prudente dans celles du Centre et de l'Est. Commençons près de chez nous, à l'Ouest, par exemple en Belgique et aux Pays-Bas.

S'il existe assez bien d'unanimité sur les éléments principaux du diagnostic, cela n'empêche pas qu'il $y$ ait de profondes divergences de vue sur leur importance relative. Le noeud du problème du chômage est le manque d'emplois dans une situation où l'offre de travail est inélastique. Ce manque d'emplois peut être attribué à trois grandes carégories de facteurs: primo, un coût de la main-d'oeuvre (trop) élevé; secundo, un certain manque de dynamisme chez l'entreprise européenne; er tertio, la crise pan-européenne. A propos de cette dernière, je serai bref. Très peu d'analystes croient que, s'il n'y avaic pas de crise, le problème du chômage serait résolu du jour au lendemain. Autrement dit, même si nous parvenions, en tant que perites économies ouvertes, à prospérer en nous laissant porter par les vagues de la conjoncture mondiale, il nous resterait encore toujours de gros problèmes à résoudre. C'est pourquoi nous allons concentrer notre attention sur les deux autres catégories de facteurs.

Les conséquences du coût relativement élevé de la main-d'oeuvre peuvent à leur tour se classer en trois catégories. Premièrement, le déplacement d'activités existantes ou l'implantation d'activités nouvelles en dehors de l'Europe. C'est le phénomène que l'on appelle de manière bizarrement ethnocentrique "délocalisation". Il se fait surtout sentir dans les secteurs des marchandises exposées au commerce international et des activités nouvelles. Deuxièmement, le remplacement de main-d'oeuvre par du capital, ou le renouvellement de procédés de production de façon à remplacer la main-d'oeuvre par une main-d'oeuvre réduite mais plus productive. Cette tendance s'observe principalement quand la production n'est guère menacée par le commerce international, ou quand le déplacement de la production existante entraînerait des frais prohibitifs. Troisièmement, le coût relativement élevé de la main-d'oeuvre peut entraîner l'abandon pur et simple de la production de biens et de services, ou du moins leur retrait du marché officiel et observable. Tous ces effets se traduisent localement par une diminution des emplois, et comme l'offre de main-d'oeuvre, elle, n'a pas fléchi, il en résulte du chômage. 
La question qui se pose dès lors concerne les raisons du coût élevé de la main-d'oeuvre. Le coût total de la main-d'oeuvre est constitué en gros de quatre composantes: (1) les salaires nets (effectivement perçus par les travailleurs), (2) les impôts dûs sur les salaires, (3) les primes retenues pour la sécurité sociale, et (4) d'autres coûts non-salariaux. Cette dernière catégorie comprend les frais de recrutement, de licenciement, de formation et de remplacement en cas de maladie ou d'absence. On peut les rassembler sous le terme "coûts d'ajustement". Une politique de l'emploi visant à réduire le coût de la main-d'oeuvre devra donc obligatoirement s'en prendre à une au moins de ces quatre composantes. Nous reviendrons plus loin sur ce sujet.

Hormis le coût élevé de la main-d'oeuvre, il y a lieu de tenir compte du deuxième facteur cité précédemment: un manque de dynamisme chez l'entreprise européenne. Deux agents principaux en sont tenus responsables: les autorités gouvernementales et les cadres supérieurs. On dit des autorités qu'elles s'adjugent une trop grande part des moyens dont l'économie dispose, qu'elles enflent de façon inconsidérée les frais généraux de production par une réglementation exagérée dans trop de domaines, et que ce faisant elles découragent le démarrage ou l'expansion d'activités productives. Quant aux cadres supérieurs, on dit que la structure financière des entreprises, la concentration industrielle et la large protection offerte par les cartels et les autorités les a bercés jusqu'à l'indolence. Les entrepreneurs de nos pays sont insuffisamment exposés aux forces vives de la concurrence, font preuve de trop peu de créativité, n'investissent pas assez dans la recherche et le développement. Bref, ils souffrent d'un manque d'esprit d'entreprise à la Schumpeter, l' "animal spirit". Cela contribue à une croissance économique médiocre et au sous-emploi.

Je n'ai bien évidemment pas l'intention de tracer cet après-midi les contours d'une politique complète, englobant tous ces éléments, à supposer même que j'en soie capable. Il n'y a pas si longtemps une commission à la solde du gouvernement suédois s'est hasardée à cette tâche. Elle était présidée par Assar Lindbeck et comprenait sept économistes et sociologues. Elle produisit un rapport de 200 pages, comprenant en annexe 27 articles de fond, et aboutit à 113 recommendations politiques ${ }^{3}$. Vous comprendrez sans peine que mon ambition est plus modeste.

En ce qui concerne l'Ouest, j'ai choisi de concentrer aujourd'hui l'attention sur une proposition: celle de la nécessité d'une thérapie de choc pour notre système de sécurité sociale. Voici les raisons qui m’ont amené à faire ce choix. 
Premièrement, une leçon inaugurale est entre autres une occasion de citer sans fausse honte ses propres travaux, devant un public à qui le protocole ne permet pas de répliquer. Au cas où il vous semblerait tantôt que je suis resté modéré en la matière, eh bien, sachez dès maintenant que votre impression sera faussée. Les auto-citations sont camouflées dans les notes en bas de page du texte imprimé $e^{4}$.

Deuxièmement, j'ai mentionné à plusieurs reprises, dans mes publications des dernières années, que je suis partisan d'une réforme radicale des systèmes de sécurité sociale, sans m'expliquer très clairement sur l'orientation à donner à une telle réforme. On est donc en droit de s'attendre à ce que je comble cette lacune. Troisièmement, j'estime une réforme de la sécurité sociale importante, non seulement à cause de ses retombées sur l'emploi, mais aussi parce qu'elle forme, avec d'autres instruments de politique sociale, le fondement de ce que nous avons appelé ailleurs le capitalisme social. Ce capitalisme social est le résultat d'une histoire économique et sociale spécifiquement européenne, et il faut absolument en sauvegarder l'essentiel; ce qui n'exclut pas qu'il puisse être modifié. ${ }^{5}$

Il est impossible dans le temps imparti de commenter toute la gamme existante de critiques concernant le système actuel. En plus des retombées sur l'emploi, les problèmes principaux de la sécurité sociale telle que nous la connaissons sont: l'apparente impossibilité de maîtriser les dépenses; l'inéfficacité manifeste, tant sous la forme d'effets redistributifs pervers (que l'on nomme parfois d'après un verset de Saint Matthieu, "aux riches on donnera, aux pauvres on prendra"), que parl'existence d'un groupe de personnes continuant malgré toutes les dispositions à vivre sous le seuil de pauvreté; les possibilités d'abus et de fraude; l'absence de modalités pour les cas imprévus; et enfin, le manque d'adaptation aux indéniables évolutions démographiques.

Le maintien du capitalisme social dépendra en grande partie de la mesure dans laquelle il pourra s'adapter aux critiques et aux circonstances modifiées. Si nous ne parvenons pas à mener à bien ces ajustements, alors l'Erat-gardien d'antan et l'Etat-providence d'aujourd'hui pourraient bien faire place à un Etat-cauchemar. Je suis profondément convaincu qu'en l'absence d'une réforme qui modifie la forme dans le but de maintenir le fond essentiel, l'existence même du capitalisme social serait menacée, pour ne pas dire que la stabilité politique en cette partie du globe serait compromise. 
Enfin et finalement, il y a bien entendu les retombées du dispositif actuel de sécurité sociale sur l'emploi, que j'ai déjà mentionnées et auxquelles je reviens maintenant plus en détail.

Le système de sécurité sociale, comprenant en gros la législation, les assurances et les autres dispositions sociales, a par divers canaux un impact important sur l'emploi. En premier lieu, c'est un élément-clé du coût de la main-d'oeuvre, de façon directe par la charge para-fiscale des primes, et de façon indirecte par les rigidités induites sur le marché de l'emploi et les coûts d'ajustement élevés que celles-ci entraînent. En second lieu, il provoque une augmentation considérable de la part du produit national brut que l'état s'approprie. En troisième et dernier lieu, certains commentateurs montrent la sécurité sociale du doigt comme étant responsable du manque général de dynamisme économique dans notre société. Une réforme en profondeur devrait donc être prometteuse en termes d'emploi. ${ }^{6}$

Il n'est pas difficile de constater que la charge actuelle des primes de sécurité sociale accroît dans une mesure importante le coût salarial brut. L'élimination totale de ces primes, ainsi que de la part des impôts qui sert à subventionner la sécurité sociale, équivaudrait à une diminution instantanée du coût de l'emploi de plusieurs dizaines pour cent. Mais la sécurité sociale est aussi une cause considérable de rigidité sur le marché de l'emploi. Elle influence et démotive les individus dans leurs choix de participation et de mobilité sous toutes leurs formes. Je m'explique. Le système actuel, y compris l'ensemble des lois sociales, comporte certaines erreurs de conception créant des "pièges de pauvreté" ("poverty traps"): si certaines circonstances sont réunies, l'individu peut voir l'avantage financier d'un nouveau contrat d'emploi anéanti par la perte correspondante de subventions sociales. Plus communément, cet avantage financier n'est pas tout-à-fait anéanti mais est fortement réduit, au point que beaucoup de gens seront découragés d'accepter le nouvel emploi. Je suis conscient du fait que les études économétriques n'ont guère établi l'influence précise de la hauteur des subventions sociales sur les choix d'activité des chômeurs, par exemple. ${ }^{7}$ Il semble en effet qu'une proportion importante de chômeurs accepte un nouvel emploi, même lorsque l'avantage financier en est réduit. ${ }^{8}$ Néanmoins, il y a deux raisons de ne pas nier cette influence. La première est d'ordre micro-économique, la seconde d'ordre empirique.

Nous avons tendance, en tant qu'économistes, à considérer que l'individu est sans cesse en train de faire des choix, et que ces choix dépendent de l'utilité (ou du 
revenu) caractérisant les différentes alternatives. Eh bien, imaginons un instant qu'il n'existe aucune subvention sociale, sous quelque forme que ce soir. Vous serez pour la plupart d'accord avec moi pour dire que ceci modifierair le comportement de façon significative. Ainsi, dans la situation extrême où la sécurité sociale est totalement absente, on se comportera différemment qu'en sa présence. Il suffit maintenant de reconnaître que, si une partie de ces modifications de comportement est conforme aux intentions du législateur, une autre ne l'est pas; nier l'existence de ces effers non désirés témoignerait d'un singulier manque d'imagination. La réforme de la sécurité sociale doit entre autres servir à en éliminer les effets indésirables.

Pour ceux parmi vous qui penseraient que ce genre de raisonnement est emprunté à la pensée micro-économique marginaliste, je veux cirer un "Report of the Select Committee of the House of Commons on Labourers' Wages", rapport datant de $1824 .{ }^{9}$ On y étudie trois effets indésirables des subventions salariales en vigueur à ce moment-là: les ouvriers touchant une partie de leur salaire sous forme de "Poor-rates" étaient moins productifs, ils s'arrangeaient pour se marier plus tôt et avoir plus d'enfants de façon à toucher plus d'allocations, et enfin ils contribuaient à, je cite, "the degradation of the character of the labouring class". Je rappelle que ceci se passait en 1824 , l'année où selon le même "Annual Register", le Roi des Pays-Bas s'adressait en langue néerlandaise aux Etats-Généraux rassemblés à Bruxelles, pour leur annoncer les fiançailles de son fils cadet bien-aimé avec la fille cadette de Sa Majesté le Roi de Prusse. La même année, le budget total de l'état s'élévait à environ 26 millions de florins, et laissait un surplus de 1,813,988 florins et 13 cents: des temps manifestement lointains... ${ }^{10}$

Dans toute analyse théorique des choix, il importe de distinguer les comportements en fonction des circonstances. L'individu peut avoir plus ou moins de choix. Une maladie prolongée ou une autre incapacité de travail limitent le choix sur le marché de l'emploi, par rapport à celui du chômeur fraîchement sorti de l'école. Pourtant il est utile de considérer que, en théorie et sans nier l'existence des exceptions, presque tout le monde a constamment des choix à faire, même si ces choix ne sont pas libres de contraintes, par exemple, de contraintes de santé. La question qui se pose si l'on veut réformer la sécurité sociale est, dans quelle mesure le système doit compenser ces contraintes.

J'ai aussi annoncé une observation empirique concernant le lien entre la sécurité sociale et les comportements sur le marché de l'emploi. Il est remarquable que le 
chômage soit relativement élevé et persistant chez les travailleurs non-qualifiés et, en général, parmi les groupes peu valorisés sur le marché de l'emploi. Ceci n'est pas dû uniquement, ni même principalement aux choix délibérés de ces personnes. Une meilleure explication est que, étant donné le coût actuel de l'emploi, encore enflé par les contributions sociales, les employeurs ne veulent ou ne peuvent pas exercer une demande effective envers le travail de ces groupes. $\mathrm{Si}$ on accepte que la grande majorité des personnes touchées désire réellement travailler, on peut en conclure qu'une organisation différente de la sécurité sociale devrait permettre des gains parétiens; c'est-à-dire que les deux parties pourraient y gagner, ou qu'au moins une des parties pourrait y gagner sans que l'autre n'y perde. Ce genre de raisonnement, parmi d'autres, a conduit à des propositions telles celles qui ont été avancées récemment par Drèze et Malinvaud, et qui visent à diminuer les charges sociales au bas de l'échelle salariale. "La réforme de la "Sécu" doit viser à réaliser ces gains parétiens.

Je voudrais maintenant, à l'aide de quelques graphiques, vous présenter les grandes lignes d'un nouveau système de sécurité sociale. Je considérerai non seulement le côté des dépenses, mais aussi celui du financement. A ma connaissance ce système n'a pas encore été présenté tel quel dans la littérature, mais presque tous ses éléments sont présents sous une forme ou sous une aurre dans d'autres propositions. Le système se rapproche encore le plus de celui proposé en 1985 par le "Wetenschappelijke Raad voor her Regeringsbeleid" aux Pays-Bas, quoiqu'il s'en différencie sur quelques points importants. ${ }^{12}$

L'esquisse du nouveau système est nécessairement abrégée. Il est peut-être utile de s'imaginer que nous disposons seulement d'un carton à bière dans un café pour y représenter le dispositif. La taille du carton ne permet pas de faire figurer tous les détails, même si j'espère en tout état de cause que notre carton imaginaire n'est imprimé que d'un côté.

L'élément de base du système est l'instauration d'un "Revenu Partiel Garanti" (RPG) auquel tour le monde aurait droit, et qui serait financé par la TVA. Le montant de ce RPG doit être fixé de telle sorte qu'une partie seulement des besoins élémentaires soit couverte; il ne s'agit donc pas d'un "minimex" ou d'un revenu social minimum. Pour nous fixer les idées, prenons le RPG tel que proposé en 1985 par le "Werenschappelijke Raad voor het Regeringsbeleid", soir 450 florins ou quelque 8100 francs belges. (Voir le graphique 1). Ce RPG est complètement individualisé. Tout résident et toute personne assimilée (je pense surtout aux 
travailleurs frontaliers et à tous ceux qui payent leurs impôts dans un autre pays que celui de résidence) y a droit, avec pour seule condition d'avoir atteint l'âge requis. La limite d'âge serait de 18 ans, ou moins si l'on étudie dans l'enseignement supérieur ou si l'on ne suit plus d'enseignement à temps plein. Le RPG reste une allocation minimale. Pour les salariés, le RPG prend la forme d'un impôt négatif sur le revenu, c'est-à-dire en pratique une base exonérée d'impôt.

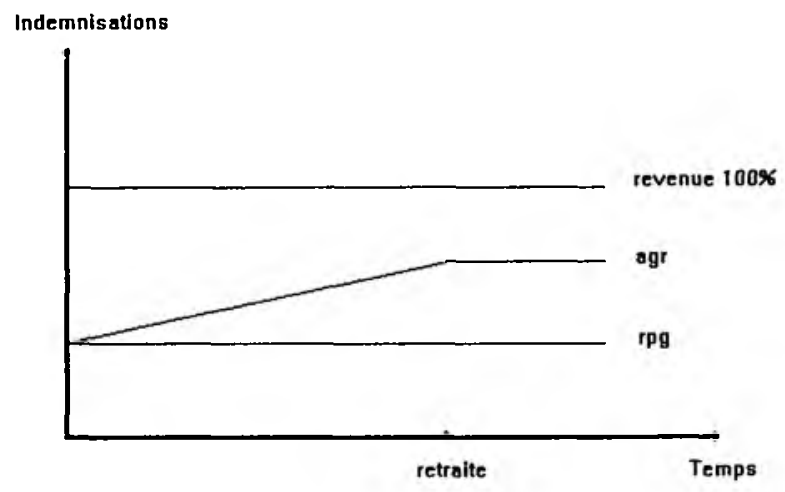

Pour compléter cette allocation minimale je propose l'instauration d'une "Assurance Générale du Revenu" (AGR). L'AGR est financée par les primes que toute personne employée est tenue de payer. Elle a strictement le caractère d'une assurance, ce qui veut dire que les indemnisations éventuelles dépendront strictement des droits accumulés par l'individu. Les primes seront versées à, et gérées par, des institutions financières contrôlées par un organe indépendant (comme la "Sociale Verzekeringsbank" aux Pays-Bas) et ne disposant d'aucun droit de refus ou de résiliation. Le montant des primes est une fonction linéaire du revenu pour tout le monde, et est fixé par la loi. Les fonds sont gérés selon un système de capitalisation et des principes actuariels stricts. ${ }^{13}$

L'assurance générale du revenu (AGR) comporte deux volets. L'AGR temporaire est destinée à couvrir la perte de revenus suite à la perte d'emploi ou à la maladie; l'AGR permanente a pour but de constituer les pensions. Elles sont administrées distinctement, mais pas nécessairement par des institutions séparées. Les assurés reçoivent dès leur premier engagement un numéro d'assurance et de pension qu'ils garderont durant toute leur carrière. Si une personne change d'employeur elle ne change pas pour autant d'assureur, et conserve tous ses droits. Il est possible aussi sous certaines conditions de changer d'assureur, mais pour des raisons actuarielles cela ne doit pas être encouragé. Les montants des indemnisations par l'AGR temporaire sont calculés en fonction du dernier salaire perçu, et pour une 
durée de temps limitée. Cette durée dépend elle-même des droits accumulés. (Voir le graphique 2). Une période couvrant les premières semaines de maladie devrait être assurée par l'employeur lui-même, et tomberait donc en dehors de l'AGR. Les montants des indemnisations de l'AGR permanente sont calculés en fonction des droits accumulés et des tables de mortalité. Les indemnisations ne sont pas transmissibles, même pas en cas de décès.

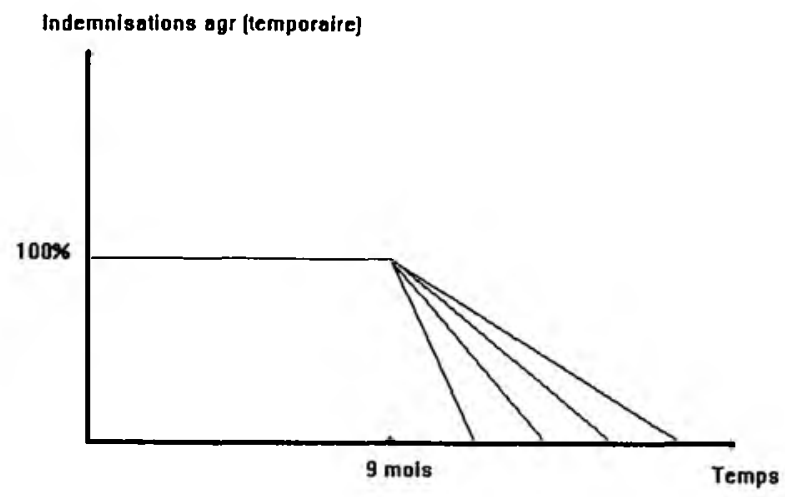

Le Revenu Partiel Garanti (RPG) est destiné à tous ceux qui satisfont des conditions minimales. Une personne qui perd son revenu suite à la perte de son emploi ou à une maladie prolongée touchera un montant comprenant, en plus du RPG, une indemnisation établie selon ses droits à l'AGR. Sur le graphique, ce montant total est exprimé en pourcentage du dernier salaire perçu, pour une personne ayant commencé à travailler à l'âge de 18 ans et ayant toujours travaillé le même nombre d'heures. On remarquera la croissance de l'indemnisation en fonction de l'âge et de la carrière.

La durée de l'allocation est représentée sur le graphique suivant. L'allocation reste d'abord constante durant les 9 premiers mois d'intervention, puis elle diminue progressivement jusqu'au moment où elle atteint le niveau du RPG. ${ }^{14}$ Le rythme de la diminution, c'est-à-dire la pente de la courbe représentant l'allocation, dépend des droits accumulés, c'est-à-dire de la durée de contribution. Selon que la personne a travaillé plus ou moins longtemps, elle a droit plus ou moins longtemps à une allocation complémentaire en sus du RPG.

Les bases du système sont maintenant posées, à une chose près. Il y manque encore une disposition assurant les moyens de (sur)vivre aux personnes "faibles", qui n'ont pas véritablement le choix ou la possibilité de subvenir à leurs propres 
besoins. Je pense ici à trois catégories de personnes: les enfants, les handicapés et les invalides permanents. Ils jouiront d'un régime à part (graphique 3). Les enfants recevront, par la personne de leurs parents ou tuteurs, un "Revenu Partiel Enfants" (RPE) remplaçant les allocations familiales. Les autres personnes privées de la capacité d'acquérir un revenu par leurs propres moyens, auront droit à un "Revenu Social Garanti" (RSG) devant leur permettre de mener une vie indépendante. Le montant précis de ces revenus sociaux doit encore être étudié. Il ne sera pas toujours facile de décider si quelqu'un appartient ou non à la catégorie des invalides permanents. Un cas illustrant bien ce problème est celui des intoxiqués. Je ne pense pas tant ici aux drogués, qui sont relativement peu nombreux, mais surtout aux intoxiqués alcooliques. On estime que les Pays-Bas comptent aujourd'hui quelque 600.000 alcooliques, dont seuls $35 \%$ ont un emploi; cela signifie que 390.000 dépendent actuellement d'une subvention sociale, dans le cadre des lois WAO, AAW, WW, ou de l'Assistance Publique. ${ }^{15}$ Dans quelle mesure peut-on parler pour ce groupe de la présence ou de l'absence de choix? Dans quelle mesure la société peut-elle et veut-elle assumer le coût de leur toxicomanie, et est-elle prête à accepter ses conséquences sociales sans autre intervention qu'une subvention sociale? Il faut élaborer la politique sur ce point, mais comme vous l'aurez remarqué notre petit carton à bière commence à manauer de place.

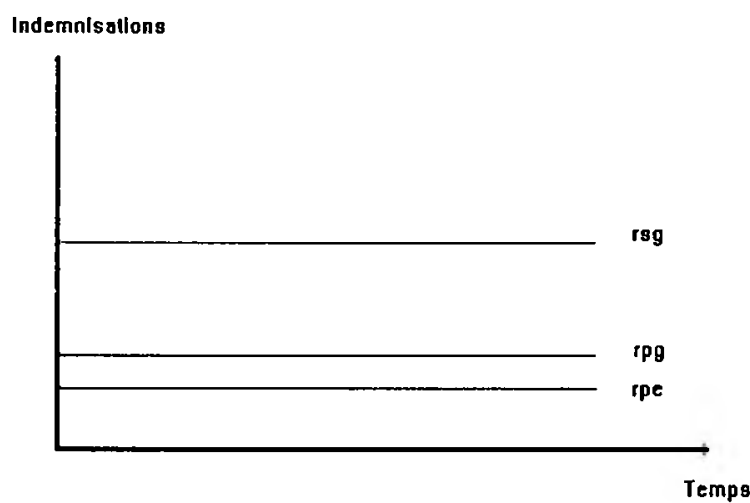

Le temps prévu pour cette leçon inaugurale ne permet pas non plus d'élaborer tous les raffinements et dispositions complémentaires, qui n'en sont pas moins indispensables. Je n'en mentionnerai donc que trois. Premièrement, la réglementation proposée remplace obligatoirement TOUS les transferts de revenu actuels aux individus et aux ménages, $\mathrm{y}$ compris les subsides au logement, bourses 
d'études etc. A défaut, l'on recréerait des pièges de pauvreté. Deuxièmement, la loi doit interdire la couverture collective d'autres risques par le biais des C.C.T. (Dans le jargon de La Haie on parle de couverture "bouche-trous". ${ }^{16}$ )

Toute convention de ce genre doit être vue comme un complot des "insiders" contre les "outsiders" sur le marché de l'emploi, alors que ces mêmes insiders tiennent les autorités responsables de la misère qui s'en suit. Troisièmement, le système doit être flanqué de services sociaux assistant les individus dans leurs efforts pour acquérir un revenu par leurs propres moyens. Sans entrer ici dans les détails, on peut penser à un accompagnement aux niveaux scolaire, formation continue et recherche d'emploi, à une assistance pour le démarrage d'une activité indépendante ou d'une entreprise, etc... Dans ma vision, ces services seraient offerts par les services sociaux, CPAS, bureaux de l'emploi, chambres de commerce. Eux non plus ne pourraient pas octroyer de subventions supplémentaires, mais ils pourraient bien fournir aux personnes dans le besoin une aide en nature (par exemple un logis temporaire) et leur rendre des services gratuits.

Cette dernière disposition est fort importante. Pour une grande partie des gens au bas de l'échelle sociale, doubler les allocations actuelles ne suffirait pas encore à les sortir de la misère. Seule une assistance sociale réelle, les aidant à survivre par leurs propres moyens et leur apprenant à faire des choix rationnels, a des chances d'aboutir. Donner plus d'argent signifie dans beaucoup de cas subsidier soit un comportement financier insensé, soit la toxicomanie, et ne mène donc à rien. Une assistance sociale étendue et améliorée, par contre, peut relever de façon durable la qualité de vie des personnes concernées.

Le dispositif de sécurité sociale tel que je viens de le décrire en grandes lignes presente nombre d'avantages. Comme avantages principaux on peut mentionner le fait que le nouveau système est extrêmement simple à administrer, qu'il est libre de mécanismes démotivants, qu'il n'encourage ni les abus ni la fraude, qu'il stimule la demande de produits domestiques, qu'il fait baisser les prix à l'exportation, et qu'il entraîne une diminution importante du coût de l'emploi. Enfin, le nouveau système a comme avantage que la responsabilité pour la sécurité sociale est centrée là où elle appartient dans une démocratie moderne: auprès du gouvernement et du parlement plutôt que chez les partenaires sociaux. Ceci n'implique aucunement la négation du rôle historique qui a été rempli par les syndicats lors de l'elaboration du capitalisme social actuel; il s'agit plutôt de reconnaître que la réalité économique exige aujourd'hui une forme adaptée. 
En comparaison avec les systèmes existants, le dispositif présenté ci-dessus est moins stigmatisant pour ses bénéficiaires et plus discret, attentif à respecter leur vie privée. Il est plus égalitaire, évitant toute discrimination sexuelle ou autre; mais il répartit le risque de manière à protéger relativement mieux les personnes âgées. Il suscite moins d'abus, ne crée pas de pièges de pauvreté, n'entraîne pas de "moral hazard" et n'a pas d'effets reditributifs pervers. Il est considérablement plus simple à administrer, et partant meilleur marché. Sa structure financière basée sur la capitalisation des primes est conçue de manière à résister aux évolutions démographiques, et est donc tenable même à très long terme.

Le système proposé est aussi neutre par rapport aux choix importants des individus. Par exemple, il n'a pas d'effets démotivants propres à influencer les personnes devant décider de leur participation au marché de l'emploi, de leur mise en ménage, etc. En cas de chômage, il n'encourage pas à dédaigner les emplois temporaires, les emplois à temps partiel, ou les emplois moins rémunérateurs que le précédent.

Le nouveau système est en outre flexible. Il rend parfaitement possibles toutes sortes de raffinements, tels une assurance contre l'absence au travail due aux maladies d'enfants, des programmes de recyclage et de formation tardive, permanente ou continue, un âge de pension flexible...

Finalement, grâce au financement du RPG par la TVA, le nouveau système entraîne une diminution importante du coût de l'emploi, une demande accrue de produits domestiques, une baisse des prix à l'exportation, et une participation accrue des secteurs à fort cóefficient de capital aux frais du bien-être social. Le financement par la TVA réduit en effet au minimum la répercussion de la sécurité sociale sur les salaires.

Je ne puis terminer cette partie de mon exposé concernant l'Europe de l'Ouest sans répondre à deux questions pressantes. Premièrement, n'y a-t-il pas d'alternatives pour cette réforme malgré tout pénible? Et deuxièmement, la thérapie de choc proposée est-elle réalisable en pratique?

Notre collègue Jules Theeuwes a récemment formulé une alternative plus radicale que la réforme sous le titre éloquent de "Abolition de l'Etat-Providence". ${ }^{17} \mathrm{Il}$ tentait, dans une colonne d'opinion, de dénombrer tous les arguments pour jeter le bébé avec l'eau du bain, et en comptait dix. Il ajoutait qu'aucun économiste ne 
les soutient, qu'aucun programme de parti ne les mentionne, et qu'il ne se trouve même pas un fou pour les prôner. Mais sa provocation a le grand attrait de la simplicité, et la netteté du radicalisme. Si nous devons choisir entre l'amputation totale sans anesthésie à la Theeuwes, et une intervention importante sous anesthésie locale, eh bien, j'ai tendance à préférer la deuxième solution. Cependant, il y a encore beaucoup de gens bien-pensants convaincus qu'une dose de chirurgie esthétique, combinée avec un régime, suffira pour faire des miracles. Les interventions plastiques auraient pour but de corriger les quelques imperfections du système actuel, tandis que le régime prendrait la forme d'une modération salariale généralisée devant sauvegarder notre compétitivité.

Corriger les imperfections du système actuel s'est déjà avéré plus difficile qu'on ne l'espérait au départ. Je vous rappelle les tentatives pénibles et qui ont bien failli être abandonnées, faites aux Pays-Bas pour maîtriser le volume des allocations pour incapacité de travail ("WAO"). Les grondements, dans ce même pays, suite au gel des dépenses en matière des pensions, illustrent aussi la résistance que rencontreront les chirurgiens plasticiens dans leur travail. Il en va de même des négociations avortées dans le cadre d'un chimérique "pacte social" en Belgique. L'opposition politique de minorités de blocage s'est avérée jusqu'à présent irrésistible dans la plupart des pays européens. Tant qu'il restera possible de mobiliser des groupes importants d'électeurs et de syndiqués, il restera difficile, sinon impossible, de modifier le système, pour ne pas parler de réformes plus importantes. Il s'en suit que les segments de la société les moins organisés, et donc les plus faibles, deviendront inévitablement les victimes d'éventuelles mesures d'économie. Or, depuis Bismarck et Beveridge, ne nous a-t-on pas enseigné que la sécurité sociale doit précisément viser à protéger ces membres les plus faibles dans la société? ${ }^{18}$ Donc, dans la mesure où les chirurgiens plasticiens s'acharnent principalement sur les patients sans défense plutôt que sur les plus laids, leur intervention ne représente pas une réelle alternative pour une réforme bien pensée.

Qu'en est-il de l'effectivité d'un bon régime salarial? Sans vouloir suggérer que la modération salariale est entièrement superflue, ses résultats sont on ne peut moins spectaculaires. Le taux de chômage s'écrirait encore longtemps en deux chiffres, si la modération salariale devait rester le seul remède. ${ }^{19}$ Partant de l'observation que le salaire journalier d'un travailleur chinois comporte à peu près un centième de celui d'un ouvrier belge ou hollandais, il faudrait une modération vraiment très drastique si les salaires devaient être notre seule arme dans le combat 
concurrentiel. Avec des réductions salariales aussi draconiennes, les trottoirs autour de la Bourse ou du "Damrak" seraient trop étroits pour les nombreux épargnants désespérés mettant une fin brutale à leurs jours. La modération salariale est certes utile, tout comme certaines autres mesures d'économie, mais toutes celles-ci ne peuvent pas remplacer une réforme en profondeur.

Malgré cela, je veux mentionner explicitement un cas particulier: le coût salarial dans une grande partie du secteur tertiaire peut être réduit d'un coup d'un sixième par l'abrogation de la TVA sur les services personnels. Je pense ici à la TVA que vous et moi payons lorsque nous faisons réparer notre voiture ou lorsque nous faisons repeindre la cuisine par un peintre professionnel. Il y a trois ou quatre bonnes raisons de réduire à zéro le taux de TVA sur les services. Premièrement, il y a l'argument théorique du "cost disease model", formulé avec tant d'éloquence en 1966 par William Baumol er William Bowen, dans leur étude "Performing Arts: The Economic Dilemma". L'essentiel de l'argument est que les prix relatifs des services doivent nécessairement augmenter dans les secteurs où par défınition la productivité ne peut guère augmenter. Par exemple, la productivité de virtuoses jouant dans une salle de concert un quartet de Mozart est aujourd'hui essentiellement la même que du temps où Mozart en écrivait la partition. Il semble inconsidéré d'accentuer encore l'augmentation inévitable de ces prix par une taxe. La deuxième raison que j'ai pour annuler la TVA sur les services est une question de principe. Je n'ai pas la faculté de comprendre pourquoi je dois payer une TVA sur les services de mon garagiste, mais pas sur ceux de mon banquier. Je trouve plus juste d'éliminer la discrimination entre les services soumis à la TVA et ceux qui y échappent. Troisièmement, j'ai un argument pragmatique. Beaucoup de services requièrent peu de qualifications, par exemple les services domestiques. Diminuer les coûts salariaux de ce type de services encouragerait leur retour vers le secteur de marché (officiel). (Par exemple, nous ne peindrions plus notre cuisine nous-mêmes, mais la ferions plus volontiers rafraîchir par un peintre professionnel.) Un tel glissement du secteur domestique vers le secteur de marché serait particulièrement favorable à l'emploi des groupes les moins qualifiés et les plus touchés par le chômage. Finalement, mentionnons qu'une réduction de la TVA est considérablement plus simple à réaliser que le système de chèques domestiques proposé par J. Delors dans son "livre blanc". ${ }^{20}$

Dernière question ouest-européenne préoccupante: La mise en oeuvre de la réforme radicale proposée ici est-elle réellement et pratiquement possible? Je dois avouer ne pas être très optimiste. Je préfere répondre par une boutade: "La 
situation est désespérée mais pas pour autant sérieuse". ${ }^{21}$ Elle n'est pas sérieuse parce que pas encore assez critique. Le système fait entendre des craquements, mais entretemps il continue à fonctionner. Néanmoins la situarion est désespérée, parce qu'il y a trop de droits acquis et d'intérêts établis à défendre dans le système actuel, et leur défense est trop bien organisée. Par contre, ceux qui sont les vrais intéressés, démunis et impuissants, n'ont pas voix au chapitre. Dans l'arène politique, l'idée du revenu partiel garanti ne rencontre guère d'échos. ${ }^{22} \mathrm{On}$ semble considérer cette idée comme issue d'anciens rêveurs hippies dans leur quarantaine. Rien n'est moins vrai. L'idée d'un tel revenu de base généralisé sous la forme d'un impôt négatif sur le revenu a déjà été formulée en 1946, aux Etats-Unis, par George Stigler, et fut reprise en 1962 et 1964 par Milton Friedman et James Tobin, qu'on ne peut vraiment décrire comme des hippies. Malgré ce passé respectable, tous les grands partis politiques rejettent l'idée d'un revenu garanti, au nom du principe sacro-saint de "pas de salaire sans travail". Ce principe rhétorique sonne faux, au vu du maintien actuel de nombreuses personnes dans une inactivité prolongée, par le biais du chômage ou de l'assistance publique. L'hypocrisie de ce rejet politique est choquante, et serait comparable à celle du rejet du préservatif comme instrument dans la lutte contre le SIDA: au nom du principe du respect de la vie, des centaines de milliers d'êtres humains sur le continent africain seraient envoyés à la mort.

Sans doute, Mesdames et Messieurs, n'en est-il pas autrement en Europe de l'Ouest qu'en Europe de l'Est: Les gouvernants ne sont jamais tentés de démanteler le système qu'ils contrôlent. D'ailleurs, les thérapies de choc suscitent rarement l'enthousiasme des patients concernés.

J'aimerais dans ce contexte vous faire remarquer une certaine asymétrie. Les hésitations avec lesquelles nous accueillons toute proposition visant à adapter notre propre société font contraste avec notre promptitude à recommander des thérapies de choc aux pays de l'Est. Ce contraste n'est pas seulement un effet de la distance. N'est-il pas remarquable que tant d'économistes - qui par déformation professionnelle ne savent le plus souvent penser qu'en termes de changements marginaux - soient si partisans d'une thérapie de choc pour les économies de l'Est? S'agit-il d'une vengeance ultime contre Marx, Engels et Lénine? Car ce qu'on propose est en fait une contre-révolution, calculée pour défaire d'un coup leur révolution sociale dans son entièreté. Mais je ne crois pas à ce genre de conspiration. Les vraies raisons sont l'ignorance et l'imprévoyance. 
Notre ignorance est due à l'effer de surprise. Nous n'avons jamais imaginé que les pays de l'Est perdraient si rapidement et si brusquement leur foi communiste. Qui ne se rappelle pas de la doctrine selon laquelle tous les pays du monde risquaient de tomber un à un comme des dominos sous le communisme? Qui donc se serait attendu au déroulement accéléré du contraire? Nous n'y érions pas préparés. Notre ignorance a encore une autre explication. Nous sommes déformés par nos habitudes. Notre inventivité se limite souvent à extrapoler nos propres théories et nos propres expériences. Confrontés à un problème, nous ne trouvons rien de mieux que de vouloir faire ressembler la réalité le plus vire possible à celle de nos "textbooks".

Notre imprévoyance provient de notre tendance à sous-estimer l'importance et la persistance des institutions. A la chute des économies dirigistes et de leurs pouvoirs centraux, nous pensions pouvoir recommencer à neuf sur leurs ruines fumantes. C'était oublier que les institutions ont la vie dure, et que même la chute du communisme n'impliquait pas que toutes les structures de pouvoir qui en vivaient disparaîtraient en même temps. Cet oubli de notre part a permis aux dirigeants des anciennes institutions d'être les premiers à exploiter la situation et à s'enrichir dans le chaos. L'ancienne nomenclatura découvrit soudain qu'elle pouvait, sous le couvert du capitalisme, s'attirer encore plus de privilèges que par le passé, non plus par les voies politiques, mais en usant de sa position inégale dans la société et des lois brutales du marché, profitant ainsi de l'absence des lois et des normes nécessaires pour régulariser les affaires dans une économie capitaliste. C'est là un bel exemple d'un état d'anomie comme défini par Durkheim.

La maîtrise de la masse monétaire, l'abolition des contrôles de prix, la libéralisation de la production et du commerce, la suppression des subsides..., voilà autant de recommandations occidentales relativement faciles à faire et même à mettre en pratique. Mais la difficulté la plus cruciale de la reconversion était la privatisation du secteur étatique. Or c'est justement cette difficulté qui a été mal résolue dans la plupart des cas. Ne nous méprenons pas sur le sens des statistiques qui indiquent que quelque $20 \%$ des citoyens de l'Est ont déjà trouvé du travail dans le secteur privé. La grande majorité de ces gens travaille dans des entreprises privées qui existaient déjà avant 1989, ou dans de très petites entreprises. Ce dernier secteur n'est rien d'autre qu'une "bulle de savon" de commerce sur rue, et ne forme pas une base réaliste pour la croissance vers une économie capitaliste. La "bulle de savon" ne durera pas, et en cas d'une restauration communiste elle 
éclaterait très vite. Seule la Pologne semble réussir assez bien son programme de privatisations, mais il faut se rendre compte que cela est sans doute dû au fait que la Pologne a toujours connu un secteur privé relativement important.

Pourquoi la privatisation des entreprises d'état à l'Est n'a-t-elle pas mieux réussi? En 1989 il existait déjà un large consensus sur l'opportunité de ces privatisations, mais ce qui manquait était une véritable stratégie, et de fait elle manque encore toujours. A l'Université d'Amsterdam le mois dernier, Sweder van Wijnbergen a analysé dans sa leçon inaugurale les raisons du chemin de croix que parcourent les privatisations. ${ }^{23} \mathrm{Sa}$ conclusion est que le manque d'un système banquaire commercial, et la crainte du chômage et de ses conséquences sociales et politiques, sont les plus grands obstacles. Implicitement, il fait aussi état de la mission impossible des états concernés, parce que la confusion fiscale dans ces pays exigerait au moins que les privatisations soient lucratives, alors qu'en réalité elles ne rapportent quasi rien.

A ce jour, deux grandes options restent ouvertes: liquider la plupart des entreprises d'état pour limiter les dégâts, ou élaborer une stratégie de privatisation. Le collègue que je viens de citer, Sweder van Wijnbergen, a plaidé contre la liquidation de façon convaincante; il n'est pas nécessaire de recommencer ici. L'argument principal est que l'introduction soudaine d'une législation sur les faillites à l'occidentale conduirait à la fermeture de nombre d'entreprises potentiellement rentables. Il nous reste maintenant à développer une stratégie de privatisation. Ce que je veux faire maintenant, c'est en proposer une ébauche.

Partons de la réalité économique et sociale actuelle.

La réalité économique est que non seulement les entreprises d'état font des pertes, mais que ces pertes croissent à un rythme éffréné tout en s'accumulant. Les pertes sont couvertes par cinq sources de financement: les subsides directs de l'etat; le non-paiement d'impôts, de contributions sociales, et d'intérêts dûs; le non-paiement de salaires; le non-paiement de fournisseurs; et les emprunts aux banques d'état. Cette situation est intenable. Le non-paiement d'impôts, contributions et intérêts, ainsi que les subsides directs, rapprochent chaque jour le budget de l'état de la catastrophe fiscale. Le non-paiement de salaires augmente le danger d'une explosion sociale. Le non-paiement de fournisseurs engendre un cercle vicieux de défauts de paiement et de pertes consécutives. Enfin, les emprunts aux banques d'état sont une forme camouflée de subsides et font obstacle au développement d'un système banquaire commercial et sain. 
La réalité sociale est que les gestionnaires des entreprises d'état n'ont aucun motif d'améliorer leur gestion. Leur manque de discipline financière est couvert par la possibilité de financer leurs pertes sans justification et n'est d'aucune autre façon sanctionnée. De plus, les gestionnaires manquent de connaissances, de l'expérience et du savoir-faire nécessaires pour faire fonctionner leurs entreprises en accord avec les règles du marché. Et il est inutile de chercher ces connaissances ailleurs. Les syndicats non plus ne sont d'aucune aide: ils ont en général conservé leur orientation centraliste, et se préoccupent plus d'idéologie que de pratique économique. Il n'y a pas de système banquaire commercial pouvant assister en imposant une discipline financière. Bref, les réseaux formels et informels, commerciaux et financiers, qui sont si cruciaux dans nos économies manquent totalement. Il existe bien sûr des réseaux, mais ils ne sont pas adaptés à une économie de marché, et de plus dans la plupart des cas ils sont corrompus car ils se sont constitués sous l'Ancien Régime.

Toute stratégie de privatisation doit selon moi impérativement tenir compte de ces réalités. La première étape indispensable est d'imposer une discipline financière stricte aux entreprises d'état. Mais il ne faut pas l'imposer brutalement car cela reviendrait à la liquidation de fait de ces entreprises. Et pourtant, vu l'état des finances publiques, il faut bien que cela se fasse rapidement et fermement. La situation exige une forme de discipline financière qui (a) donne aux entreprises une chance de survie, et (b) permette aux responsables d'acquérir et de développer à vive allure les connaissances, le savoir-faire et les réseaux nécessaires pour survivre et fonctionner dans une économie de marché. Ces conditions pourraient sans doute être satisfaites si l'on s'y prenait de la manière suivante.

Les autorités établissent et annoncent, pour chaque entreprise d'état, un plan quinquennal détaillé, prévoyant la réduction progressive des subsides sous toutes leurs formes, jusqu'à leur élimination totale. Les montants de subsides sont spécifiés d'avance, année par année, et l'entreprise établit un plan d'action et de restructuration correspondant. Dans presque tous les cas, il sera nécessaire de décomposer les grands conglomérats en centres de profit séparés. Dans certains cas, la liquidation restera inévitable. Dans d'autres cas, une stratégie de rationalisation de l'entreprise sera possible. Exceptionnellement, la vente complète ou partielle, ou une formule de copropriété (type "joint venture") avec une société étrangère, pourront être envisagées. D'éventuels candidars occidentaux pour une reprise ou une association pourraient être impliqués dans l'élaboration de ces plans. Les autorités pourront, selon la nature de l'entreprise et les caractéristiques 
de la région où elle est implantée, moduler le rythme de la réduction des subsides, à la condition toutefois de ne jamais dépasser la durée de cinq ans. Les autorités devront aussi indiquer, pour chaque entreprise, la partie des subsides retirés qui, pour une période déterminée et selon un plan bien précis, est mise à la disposition d'un conseil régional de restructuration. Ce conseil établira une stratégie de restructuration, en consultation avec la direction de l'entreprise, les syndicats, les administrateurs locaux, et les représentants d'une banque commerciale. Ceux-ci détermineront ensemble l'usage à faire des fonds destinés à atténuer les conséquences de la restructuration. Le conseil régional doit pouvoir prendre ses décisions de façon autonome et sans contraintes. Il peut décider de donner la priorité au recyclage professionnel, mais il peut préférer soutenir le démarrage de petites entreprises. Toute mesure contribuant à initier de nouvelles activités dans le secteur du marché, ou à préparer la population professionnelle à survivre dans un environnement de marché, doit être possible, à l'exception du transfert de revenu. A nouveau, deux grands principes doivent être respectés, à savoir la discipline budgétaire et un timing strict et explicite pour la réduction des subsides. Le délai doit être précisé d'avance et ne peut pas dépasser cinq ans. L'aide des pays occidentaux et des organisations internationales pourrait être consacrée principalemement à l'assistance technique, tant aux gestionnaires des entreprises d'état qu'aux administrateurs des conseils régionaux. Les experts occidentaux s'occuperaient plus de résoudre les problèmes quotidiens de restructuration, et moins de faire des recommandations qu'ils ne doivent pas mettre en pratique eux-mêmes.

La stratégie proposée pour la privatisation a comme inconvénient principal que l'assainissement financier de l'état est remis de plusieurs années; mais les conséquences d'un assainissement brusque et immédiat seraient à mon avis néfastes. L'arrêt brutal de tous les subsides entraînerait l'éffondrement des activités économiques existantes, et aurait pour conséquence la dislocation complète de la base industrielle. De plus, on peut se demander si la population accepterait le chômage et l'apauvrissement qui s'en suivraient. La disparition des derniers vestiges de la légitimité sociale et politique des réformes mènerait soit à l'anarchie soit à une restauration communiste. Les résultats des élections récentes dans certains de ces pays ne justifient pas beaucoup d'optimisme à cet égard. Dans un article récent de "Foreign Affairs", Youri Afanasjev, recteur de l'université russe pour les sciences humaines et une des têtes de file de l'opposition démocratique, constate qu'en Russie il est peut-être déjà trop tard et que les réformes n'existent plus que dans la rhétorique des détenteurs du pouvoir. Il désespère de voir aboutir de véritables réformes. ${ }^{24}$ 
L'avantage de la stratégie de privatisation proposée est qu'elle donne aux entreprises existantes une chance de survivre et de s'adaprer à une économie de marché, sans destruction du capital. Le grand nombre de personnes dont elle exige la coopération comporte évidemment certains risques. Mais la perspective que beaucoup de gens pourraient apprendre à opérer dans un environnement de marché, neuf pour eux, compense largement ce risque et permettra peut-être de surmonter l'inertie, la passivité et le fatalisme si caractéristiques de la situation actuelle - quoique ce pari ne soit certainement pas gagné d'avance! En effet, il est inutile de nous bercer d'illusions sur l'expérience que les habitants de l'Est ont des méchanismes du marché. Quelque cinquante ans de régime communiste ont engendré une incapacité collective à penser en termes de marché et à être actif sur les marchés. En Russie, on ne peut même pas faire appel à des traditions ancestrales. Si nécessaire, on pourra relire Gogol et Tourgeniev pour rappeler à la mémoire ces aspects de l'histoire.

Si la stratégie de privatisation est essentielle, il va sans dire qu'à elle seule elle n'est pas suffisante... Une politique pro-active de l'emploi et du recyclage professionnel, des programmes de stabilisation macro-économique, l'institution d'un système valable de... Sécurité Sociale, et le développement de marchés d'exportation: voilà autant d'autres ingrédients indispensables à la réforme. Le temps imparti ne me permet pas de m'étendre sur ces sujets. Il en est un pourtant pour lequel je veux faire une exception, et qui concerne la politique commerciale de notre chère Union Européenne. Il est tout simplement scandaleux de constater l'attitude de nos pays vis-à-vis de l'Europe Centrale et de l'Est en termes de commerce extérieur. Malgré toute la rhétorique communautaire, qu'elle soit en provenance de Bruxelles, La Haye, Paris ou Londres, et qui est destinée à encourager la réforme à l'Est, nos propres frontières restent hermétiquement fermées à ses produits. Dans certains cas, nous avons même érigé de nouvelles barrières, tandis que - pour couronner ce bouquet protectionniste - nous nous y débarrassons de nos propres excès de production agricole fortement subsidiés. Ainsi le beurre belge ou hollandais est à l'Est souvent moins cher que le beurre produit sur place, et le remplace. (C'est du dumping institutionalisé au plus haut niveau.) Aucun programme de soutien ou de réforme, si bien intentionné soit-il, n'a de chances de réussite tant que simultanément on mine ce qui reste de l'économie locale. L'Union Européenne reprend d'une main deux fois ce qu'elle donne de l'autre, avec des conséquences désastreuses. C'est là un calcul borné, manquant totalement de prévoyance. Il est temps de nous interroger, et d'interpeller nos dirigeants, sur le sens de tant d'hypocrisie. 
Très chers auditeurs, je ne considère ni mes propositions de réforme de la Sécurité Sociale, ni celles qui concernent une stratégie de privatisation progressive pour l'Europe de l'Est, comme l'oeuf de Christophe Colomb. Qui a l'âge de prononcer une leçon inaugurale doir savoir que Christophe Colomb n'a jamais pondu d'oeuf, et qu'il n'a donc pas pu en léguer. J'espère néanmoins avoir fourni une contribution utile à deux débats qui à mon avis se trouvent au centre de l'actualité socio-économique des marchés de l'emploi en Europe. Cette actualité n'est donc pas seulement de nature économique, mais possède également d'indéniables dimensions sociales et politiques. Il est sans doute suffisamment évident que la stabilité économique est menacée, si nous ne parvenons pas à résoudre les problèmes du chômage en Europe Centrale et de l'Est. Mais, comme le sociologue Alain Touraine dans son livre récent "Qu'est-ce que la démocratie?", j'ai voulu attirer l'attention sur le fait qu'il est peut-être tout aussi crucial pour nos démocraties occidentales de résoudre les problèmes du chômage et de la Sécurité Sociale. Les solutions adoptées devront d'ur.s part respecter autant que possible la liberté de choix des citoyens individuels, et d'autre part contribuer à une société qui soit juste aux yeux de la majorité. Ces deux conditions sont fondamentales. J'ai la forte impression que les politiques économique et sociale menées actuellement n'y répondent souvent pas: que beaucoup de gens ont le sentiment que ce ne sont pas eux qui font les choix, mais bien des oligarchies; et que le résultat n'est pas toujours ressenti comme étant juste, loin s'en faut.

\section{REMERCIEMENTS}

Arrivé au terme de mon exposé, je voudrais respecter la tradition et prononcer quelques mots de remerciements bien sincères.

Cher Professeur Maddison, Dear Angus,

You directed my interest towards international comparative research and as you can judge from my present work, both in research and teaching, your influence has been decisive for my career. The standards you set for my Phd-work were high and I am very grateful that you taught me, more than anyone else, how to stick to these scholarly standards without letting striving for perfection inhibit publication according to certain deadlines. I remember one day when we discussed the final draft of my thesis in a road-restaurant near Sint-Niklaas. You proposed to rearrange the book by reducing the number chapters drastically and 
by turning chapter 5 in chapter 1 . I referred to the General Theory to defend my proposition but you replied that, and I quote: "You can do a better job than Keynes". I finally rearranged the book the way you proposed. However much I learned from your academic advices, your influence on other aspects of my professional life has been also important. You showed me that running a vakgroep is a game with hard rules and my naivety in this respect could be damaging for myself as well as for other people. But if I have to single out one thing that I learned from you, it would be the fact you showed me how beneficial the mix of scholarly discipline with academic anarchism and non-conformism is in your own work.

Chers maîtres, chers collègues, chers amis,

La liste des personnes qui ont contribué de manière décisive à ma formation académique est tellement longue, qu'en la préparant j'ai été pris de doutes sur mon apport personnel. Au risque d'en omettre trop, je veux tout de même en nommer quelques-uns, et en premier lieu le Professeur Deleeck. Non seulement il m'a enseigné l'économie sociale dès mes débuts à l'université, non seulement il a suscité mon intérêt pour la problématique de la Sécurité Sociale avec la vivacité d'esprit qui lui est propre, mais aussi et surtout c'est lui qui, en 1975, plié en quatre sur la banquette arrière de notre Renault 4, m'a convaincu de mettre un terme à ma carrière peu enthousiasmante de fonctionnaire bruxellois après moins d'un ans, pour aller me joindre à la Faculté d'économie de Groningen. Outre Herman Deleeck je dois remercier beaucoup d'autres de mes maîtres: Louis Van Bladel, Coen Boey, et le regretté Wim Thijs, qui m'ont initié au monde fascinant de la philosophie; Karel Van Isacker, Herman van der Wee et Herman Daems qui m'ont transmis leur enthousiasme pour l'histoire; le défunt Gaston Eyskens, qui m'apprit en tant que professeur et premier ministre qu'un budget public ne s'établit pas uniquement selon les règles des finances publiques; Mark Eyskens qui me fit comprendre l'importance de la théorie micro-économique; et Theo Peeters qui en fit autant pour l'économie internationale.

Une fois mis au travail à l'université de Groningen il s'est avéré que ma formation était loin d'être achevée, même si elle changea de nature. Je pense encore avec beaucoup de plaisir académique et social au groupe d'économie sociologique. J'y trouvai dans les personnes du regretté Cees de Galan, de Iwan Gadourek, Tjerk Huppes, Eric Bax, Rik Derveld et Eddy Szirmai, un club d'amis prêt à pallier mon manque d'expérience avec tant de bienveillance que je m'en étonne encore aujourd'hui. Il me donnèrent l'occasion de forger pour devenir forgeron, ainsi 
que le firent plus tard mes collègues historiens. Depuis ce temps-là je n'ai pas arrêté d'avoir des discussions interminables avec Ed Szirmai, dont j'ai appris plus que je ne puis résumer en quelques phrases. D'autres collègues également m'ont beaucoup apporté, et je pense surtout à Simon Kuipers, Piet Keyser et, surtour, Joan Muysken, qui un beau jour décida le plus simplement du monde que nous devions faire quelque chose ensemble. Je lui reste reconnaissant pour cette collaboration que nous avons d'ailleurs pu poursuivre à Maastricht.

J'ai aussi beaucoup appris de mes amis étudiants et je veux citer ici en particulier les membres de feu le groupe "Keetje Tippel" où nous developpâmes notre intérêt académique commun pour l'histoire économique et sociale, mais où nous décidâmes finalement de préférer encore le "Droit à la Paresse" de Paul Lafargue. A toutes ces personnes j'exprime ici ma sincère gratitude.

Je veux aussi adresser un mot de remerciement très spécialement à mes parents. Leur contribution à ma formation est difficile à traduire en mots, mais je tiens tout-de-même à les remercier pour trois choses en particulier. Premièrement, pour le climat intellectuel à la maison, où la curiosité, la lecture et l'étude étaient des choses qui allaient de soi. Deuxièmement, pour la philosophie selon laquelle rien dans la vie ne donne d'agrément sans sens de l'humour et du relatif des choses. Et troisièmement, pour les innombrables discussions à table, tant en famille que lors des fréquentes visites d'amis. Ces discussions m'ont d'ailleurs appris que dans le torrent de la conversarion et des raisonnements entrecroisés, il faut savoir élever la voix pour se faire entendre.

Enfin, je m'adresse aux personnes avec qui je travaille ici à Maastricht ainsi qu'à Liège.

Mesdames et Messieurs des Chambres de Commerce et de l'Indusrie de Maastricht et environs et du pays minier, La faculté des sciences économiques vous est très reconnaissante de votre décision de fonder une chaire spéciale en économie eurégionale. Moins de deux ans après sa fondation nous pouvons déjà faire état de plusieurs projets de recherche de petite ampleur qui ont abouti. Très prochainement nous démarrerons deux plus grands projets, et de nombreux autres sont en préparation. L'intérêt que ces activités suscitent au sein de la Commune de Maastricht, de la Province du Limbourg (hollandais), des Chambres des Frontières eurégionales, et d'autres organisations régionales, témoigne du manque que la chaire a comblé. En tant qu'occupant de la chaire j'espère 
pouvoir contribuer positivement à une entente accrue entre toutes les parties, par-delà les frontières. Je vous suis reconnaissant pour la confiance que vous me témoignez.

Mesdames et Messieurs de la Faculté des Sciences Economiques de la Rijksuniversiteit Limburg à Maastricht, Le temps écoulé depuis mon arrivée parmi vous et jusqu'à cette inauguration, a été largement suffisant pour que vous sachiez aujourd'hui exactement à qui vous en tenir. Si je viens presque toujours ici avec plaisir, c'est en grande partie grâce à vous. Je vous suis fort reconnaissant pour l'amitié, le bon esprit et la confiance qui règnent ici. J'apprécie beaucoup la liberté que vous m'octroyez d'accomplir mes tâches à ma manière parfois un peu particulière. Je pense aussi avec un plaisir reconnaissant à la gaieté et l'efficacité du personnel administratif. Beaucoup des choses qu'entreprend le personnel scientifique ne sont possibles que grâce au soutien et à la coopération des secrétaires, des secrétariats de faculté s'occupant de la programmation des cours et des examens, du bureau pour l'internationalisation, etc. Je veux exprimer le voeux, en tant que capitaine du plus jeune et plus petit navire de la flotille facultaire, d'en rester une unité loyale à travers vents et marées. L'essentiel est cependant que la brise nous fasse respirer de l'air frais, et je ne puis vous cacher que ces derniers temps je commence à me faire du souci à ce sujet. A en juger par le budget à long terme et la présentation qu'en fait la direction, celle-ci a tendance à subir les problèmes qui surgissent, exactement comme nos étudiants que nous soumettons à des méthodes d'apprentissage à base de problèmes. J'espère beaucoup que nous parviendrons dans un avenir proche à surmonter la morosité qui semble actuellement nous gagner.

Mesdames, Messieurs de la Faculté d'Economie, de Gestion et des Sciences Sociales de l'Université de Liège,

Tout Belge que je suis, mon accent n'est pas le vôtre, et je fais figure d'étranger parmi vous.

Mais chaque semaine, je suis séduit par votre hospitalité et vorre accueil. J'espère qu'au cours des années à venir, nous aurons l'occasion d'apprendre à mieux nous connaître et d'établir une collaboration fructueuse.

Mesdames et Messieurs les étudiants de la Faculté d'Economie à Maastricht,

La science et l'étude sont des choses passionnantes si, en plus de l'auto-discipline indispensable, elles sont assaisonnées d'une bonne dose d'entêtement, de non-conformisme, d'audace et d'enthousiasme. Ces qualités, je les retrouve 
souvent chez vous, et de ce point de vue-là, je prends souvent le plus grand plaisir à vous suivre et guider. Je jouis de votre enthousiasme et de votre ardeur, et je veux continuer à les stimuler dans les années qui viennent.

Mesdames, Messieurs les étudiants à l'Université de Liège, Mon expérience parmi vous est encore limitée. Pourtant je puis déjà dire sans exagérer que je me rends avec un réel plaisir au Sart-Tilman pour y donner cours. Votre modestie pas entièrement justifiée me surprend souvent, et je veux m'efforcer dans les années qui viennent de contribuer utilement à votre formation, ainsi qu'au développement et à la valorisation de vos qualités professionnelles.

Ladies and Gentlemen students in International Economic Studies,

I promised you an adventure when you started your study in our new graduate programme. I am very glad that you were prepared to take the risk of being adventurous. Be sure that $\mathrm{I}$, myself and the staff of the graduate programme are dedicated to turn our journey into a success.

Chers amis, jadis nous trouvions que les professeurs avaient souvent un problème de communication bien particulier, et qu'ils étaient même atteints d'une légère tendance à l'autisme. Quoique nos jugements soient devenus moins sévères avec le temps, je voudrais quand-même vous prier de me corriger à temps dès que les premiers symptômes de ce syndrôme se manifesteraient chez moi.

Très chers auditeurs,

En ces temps où il n'est pas toujours clair s'il faut agiter un produit avant l'emploi, je veux terminer sur une quasi-certitude. Je suis quasi-certain de devoir attendre encore au moins sept ans avant que ma fille ne fasse de devoirs d'économie. D'ailleurs, je ne m'attends pas à ce qu'elle ait besoin de mon assistance, encore moins à ce qu'elle me la demande. Il faudra donc bien que je m'occupe autrement dans les années à venir.

J'ai dit. 


\section{NOTES}

1. cité par Bohets, J., De frustraties van de ekonoom, Bohets, J., De Standaard, 5 mars 1994.

2. J'ai récemment estimé le taux de chômage en Bulgarie à environ $21 \%$ selon les starisriques du travail. Le taux de chômage dans les "Neue Bundesländer" a été évalué à environ $40 \%$.

3. Assar Lindbeck et al., Options for economic and politic reform in Sweden, Economic policy, octobre 1993, pp. 219-264.

4. Pour plus de détails, consulter: Kerckhoffs, C., Neubourg, C. de, et Palm, F., The determinants of unemployment and jobsearch duration in the Netherlands, in The Economist, no142, 1994, pp 21-42, Kluwer Academic publishers.

Neubourg, C. de, De Belgische en Nederlandse arbeidsmarkt in een internationaal vergelijkend perspectief, Maandschrift Economie, 1993.

Muysken, J. et Neubourg, C. de, Hoe sociaal is de EG? Her sociale beleid, in Muysken J. et Soete L. (éds.), Maastricht 1991 kritisch beschouwd, Preadviezen 1993, Koninklijke Vereniging voor de stadhuishoudkunde, Edition Lemma, Utrecht, 1993, pp 27-57.

Neubourg, C. de, The choice was ours: unemployment policy in an international comparative perspective, in Verhaar C. (éd.), On the Mysteries of Unemployment, Kluwer, Deventer, 1992, pp 317-333.

Neubourg, C. de, The Art of Full Employment, North Holland, AmsterdamNew York, 1991.

Neubourg, C. de, Job libido and the culture of unemployment; an essay in sociological economics, in Coughlin R. (éd.), Morality, Rationality and efficiency: New perspectives on Socio-Economics, M.E. Sharp, New York, 1991, pp 61-78.

5. Muysken, J. en Neubourg, C. de, Hoe sociaal is de EG? Het sociale beleid, op. cit., pp 27-57. 
6. Voir pour de plus amples informations: Geleijnse, L., Vrooman, JC. en Muffels, R.J.A., Tussen ministelsel en participatiemodel; een verkennende studie naar stelselvarianten in de sociale zekerheid, Sociaal en Cultureel Planbureau, La Haye, décembre 1993.

7. Voir pour plus de détails: Neubourg, C. de, Unemployment and labour market flexibility: the Netherlands, B.I.T., Geneve, 1990.

8. Voir "The world according to Jantje van Leyden" in Coughlin (ed.)

9. The annual register or a view of the history, Politics and literature of the year 1824, London, Baldwin, Cradock and Joy, 1825, Appendix to chronicle; public documents, p. 48.

10. Ibidem, chapter XI, p 160.

11. Drèze, J. and Malinvaud, E., Growth and employment; the scope of an european initiative, papier présenté au "Annual Meeting of the European Economic Association”, Helsinki, septembre 1993.

12. Wettenschappelijke Raad voor het regeringsbeleid, guarantees for security, no. 33, La Haye, Government Publishing Office, 1985.

13. On peut craindre que les fonds ainsi crés prennent de l'importance dans le sens où ils disposeront de grosses sommes pour investir. Il serait souhaitable de contrecarrer cette concentration de pouvoir en créant divers fonds de taille réduite.

14. La limite des neuf mois a été choisie car les recherches empiriques montrent que les chances de retrouver un emploi commencent à diminuer sérieusement après ces neufs mois. Cela va sans dire qu'à partir de cette période, il faut introduire dans le système un incitant pour stimuler les chômeurs à chercher plus activement un travail. De cette manière, cela compense la diminution des opportunités d'emplois. Voir Kerchoff, C., Neubourg, C. de, et Palm, F., The determinants of unemployment and job research duration in the Netherlands, op. cit., pp 21-42.

15. Ces chiffres proviennent du rapport annuel CAD, Limbourg, 1993.

16. On peut prendre individuellement une assurance complémentaire privée.

17. Theeuwes, J.J.M., Afschaffing van de welvaartstaat, in Economisch statistische Berichten, 23 février 1994, no. 3950, 79 ième année, p 167. 
18. L'Etat providence servirait encore une fois le profit et le pouvoir des classes moyennes plutôt que les besoins des plus pauvres. Voir aussi Swaan, A. de, Incare of the state: health care, education and welfare in Europe and the USA in the Modern Era, 1988.

19. En outre, il faut remarquer que les coûts salariaux ne représentent qu'une partie limitée des coûrs de producrion totaux. D'après des données récentes de l'Union des Entreprises Néérlandaises (V.N.O.), il s'avère que seulement $1 \%$ des entreprises exportatrices sont génées par des coûts salariaux significatifs; ce sont surtout les petires et moyennes entreprises qui sont un peu plus touchées. Au niveau international, des salaires élevés sont associés à un degré de développement accru.

20. Delors, J., White book, Growth, competitiveness, employment:the challenges and ways forward into the 21 st century, Commission of the European Communities, Bruxelles, 5 décembre 1993.

21. Watzlowitck, P., The situation is hopeless but not serious, traduit en Neerlandais Geluk is ook niet alles, Van Loghum Slaterus, Daventer, 1983.

22. Pour un meilleur aperçu, voir Roebroek, J.M., Hogenboom, E., Basisinkomen alternatieve uitkering of nieuw paradigma?, 's-Gravenhage, Ministere des affaires sociales et de l'emploi, 1990.

23. Wijnbergen, S. van, Oost Europa vijf jaar na de val, Oratie, Université d'Amsterdam, 18 février 1994.

24. Afanasjev, Y., in Foreign Affairs, 1993, traduction publiée dans Volkskrant, 12 mars 1994, p. 16. 